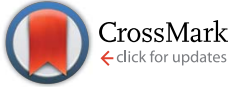

Cite this: RSC Adv., 2015, 5, 99832

Received 19th October 2015 Accepted 9th November 2015

DOI: $10.1039 / c 5 r a 21788 a$

www.rsc.org/advances

\section{Hypervalent diorganoantimony(III) fluorides via diorganoantimony(III) cations - a general method of synthesis $\dagger$}

\begin{abstract}
Ana Maria Preda, ${ }^{a}$ Ciprian I. Raţ, ${ }^{a}$ Cristian Silvestru, ${ }^{\text {a }}$ Heinrich Lang, ${ }^{b}$ Tobias Rüffer $^{b}$ and Michael Mehring*c

Novel diorganoantimony(III) fluorides containing ligands with pendant arms, $\mathrm{R}_{2} \mathrm{SbF}(5),(\mathrm{R}) \mathrm{PhSbF}(6)[\mathrm{R}=2$ $\left.\left(2^{\prime}, 6^{\prime}-\mathrm{Pr}_{2} \mathrm{C}_{6} \mathrm{H}_{3} \mathrm{~N}=\mathrm{CH}\right) \mathrm{C}_{6} \mathrm{H}_{4}\right], \mathrm{R}_{2}{ }_{2} \mathrm{SbF}(7)$ and $\left(\mathrm{R}^{\prime \prime}\right) \mathrm{PhSbF}(8)\left[\mathrm{R}^{\prime \prime}=2-\left(\mathrm{Me}_{2} \mathrm{NCH}_{2}\right) \mathrm{C}_{6} \mathrm{H}_{4}\right]$, were prepared via the ionic derivatives $\left[\mathrm{R}_{2} \mathrm{Sb}\right]^{+}\left[\mathrm{PF}_{6}\right]^{-}(1),[(\mathrm{R}) \mathrm{PhSb}]^{+}\left[\mathrm{PF}_{6}\right]^{-}(2),\left[\mathrm{R}_{2}{ }_{2} \mathrm{Sb}\right]^{+}\left[\mathrm{SbF}_{6}\right]^{-}(4)$ and $\left[\left(\mathrm{R}^{\prime \prime}\right) \mathrm{PhSb}\right]^{+}\left[\mathrm{SbF}_{6}\right]^{-}$(obtained in situ) by treatment with $\left[\mathrm{Bu}_{4} \mathrm{~N}\right] \mathrm{F} \cdot 3 \mathrm{H}_{2} \mathrm{O}$. The ionic species used as starting materials as well as $\left[\mathrm{R}_{2}^{\prime} \mathrm{Sb}^{+}\left[\mathrm{PF}_{6}\right]^{-}\right.$

(3) $\left[\mathrm{R}^{\prime}=2-\left(2^{\prime}, 4^{\prime}, 6^{\prime}-\mathrm{Me}_{3} \mathrm{C}_{6} \mathrm{H}_{2} \mathrm{~N}=\mathrm{CH}\right) \mathrm{C}_{6} \mathrm{H}_{4}\right]$ were obtained from the corresponding bromides or chlorides and $\left.\mathrm{Tl}_{[\mathrm{PF}}\right]$ or $\left.\mathrm{Ag}_{\mathrm{SbF}}\right]$. The compounds were investigated by multinuclear NMR spectroscopy in solution, MS and IR spectroscopy in the solid state. The molecular structures of the ionic species $1 \cdot 2 \mathrm{CH}_{2} \mathrm{Cl}_{2}$ and $3 \cdot 2 \mathrm{CHCl}_{3}$ as well as of the fluorides $5-8$ were determined by single-crystal $\mathrm{X}$-ray diffraction.
\end{abstract}

\section{Introduction}

The interest in the development of new sensors for the potentially toxic fluoride anion led to recent achievements based on main group chemistry and, particularly, organoantimony(III) and -antimony(v) compounds..$^{1-6} \mathrm{~A}$ survey of the literature concerning organoantimony(III) fluorides revealed some interesting aspects with regard to the preparation of the few $\mathrm{R}_{2} \mathrm{SbF}^{7-12}$ and $\mathrm{RSbF}_{2}$ (ref. 11-14) species reported so far. In earlier works $\left[\mathrm{NH}_{4}\right]_{2}\left[\mathrm{PhSiF}_{5}\right]$ was used for phenylation of $\mathrm{SbF}_{3}$ in aqueous solution to give $\mathrm{Ph}_{2} \mathrm{SbF}^{7,8}$ This is, so far, the only $\mathrm{R}_{2} \mathrm{SbF}$ species investigated by single-crystal X-ray diffraction; its solid state structure consisting of infinite chains of $\mathrm{Ph}_{2} \mathrm{SbF}$ units connected by strong intermolecular fluorine bridges. ${ }^{8}$ It should be noted here that organotin(Iv) fluorinating agents such as $\mathrm{Me}_{3} \mathrm{SnF}$ or $\left[2-\left(\mathrm{Me}_{2} \mathrm{NCH}_{2}\right) \mathrm{C}_{6} \mathrm{H}_{4}\right] \mathrm{Sn}\left({ }^{n} \mathrm{Bu}\right)_{2} \mathrm{~F}$ were used successfully in halogen exchange reactions to prepare organoantimony(III) difluorides of the type $\left[2,6-\left(\mathrm{YCH}_{2}\right)_{2} \mathrm{C}_{6} \mathrm{H}_{3}\right] \mathrm{SbF}_{2}\left(\mathrm{Y}=\mathrm{MeO},{ }^{t} \mathrm{BuO}\right.$,

${ }^{a}$ Departamentul de Chimie, Centrul de Chimie Supramoleculară Organică şi Organometalică (ССSOOM), Facultatea de Chimie și Inginerie Chimică, Universitatea Babeș-Bolyai, 400028 Cluj-Napoca, Romania. E-mail: cristian. silvestru@ubbcluj.ro

${ }^{b}$ Institut für Chemie, Technische Universität Chemnitz, Anorganische Chemie, D-09111 Chemnitz, Germany

'Institut für Chemie, Technische Universität Chemnitz, Koordinationschemie, D-09111 Chemnitz, Germany

$\dagger$ Electronic supplementary information (ESI) available: NMR numbering schemes; X-ray crystallographic data in CIF format for $\mathbf{1} \cdot 2 \mathrm{CH}_{2} \mathrm{Cl}_{2}, 3 \cdot 2 \mathrm{CHCl}_{3}$ and 5-8; figures representing the optical isomers as well as the supramolecular architectures in the crystals of these compounds. CCDC 1020707-10207012. For ESI and crystallographic data in CIF or other electronic format see DOI: 10.1039/c5ra21788a
$\left.\mathrm{Me}_{2} \mathrm{~N}\right)$ from the corresponding dichlorides containing $(O, C, O)$ or $(N, C, N)$-pincer ligands. ${ }^{13}$ The difluoride $\left[2,6-\left(\mathrm{Me}_{2} \mathrm{NCH}_{2}\right)_{2}-\right.$ $\left.\mathrm{C}_{6} \mathrm{H}_{3}\right] \mathrm{SbF}_{2}$ was also obtained by reacting the oxide $\left[\left\{2,6-\left(\mathrm{Me}_{2}-\right.\right.\right.$ $\left.\left.\left.\mathrm{NCH}_{2}\right)_{2} \mathrm{C}_{6} \mathrm{H}_{3}\right\} \mathrm{SbO}\right]_{2}$ and $\mathrm{HBF}_{4} \cdot \mathrm{Et}_{2} \mathrm{O}$ as result of a polar group exchange. ${ }^{14}$

Several other methods failed to produce the desired $\mathrm{Ph}_{2} \mathrm{SbF}$ derivative. ${ }^{8}$ Thus, the reaction of $\mathrm{Ph}_{2} \mathrm{SbCl}$ with $\mathrm{AgF}$ in acetonitrile and $\mathrm{AsF}_{3}$ afforded the organoantimony(v) species $\mathrm{Ph}_{3} \mathrm{SbF}_{2}$ following a process of simultaneous oxidative fluorination and redistribution of the phenyl groups. The redistribution reaction between $\mathrm{R}_{3} \mathrm{Sb}$ and $\mathrm{SbX}_{3}(\mathrm{X}=\mathrm{Cl}, \mathrm{Br})$ in absence of any solvent, ${ }^{15-18}$ or the halogen exchange reaction between $\mathrm{R}_{2} \mathrm{SbCl}$ and $\mathrm{KBr}$ or $\mathrm{NaI},{ }^{17,18}$ worked very well for the preparation of chlorides, bromides or iodides. By contrast, no reaction occurs between $\mathrm{Ph}_{3} \mathrm{Sb}$ and $\mathrm{SbF}_{3}$ in $\mathrm{CH}_{2} \mathrm{Cl}_{2}$ or $\mathrm{MeOH}$ solutions, at reflux, or in absence of a solvent, or between $\mathrm{Ph}_{2} \mathrm{SbCl}$ and $\mathrm{KF}$ even after long periods of heating at reflux in methanol. ${ }^{8}$ However, the fluorination was effective when the dibenzoazastibocine chloride $\mathrm{MeN}\left(\mathrm{CH}_{2} \mathrm{C}_{6} \mathrm{H}_{4}\right)_{2} \mathrm{SbCl}$ was reacted with $\mathrm{KF}$ in DMF solution. ${ }^{9}$ While the partial phenylation of $\mathrm{SbF}_{3}$ with $\mathrm{PhLi}$ or $\mathrm{PhMgBr}$ reagents failed, the isolated product always being $\mathrm{Ph}_{3} \mathrm{Sb}$ regardless of the molar ratio of the reagents used, ${ }^{8}$ for other organolithium reagents the reaction with $\mathrm{SbF}_{3}$ led to the desired organoantimony(III) fluorides, ${ }^{10-12}$ even if the stoichiometry could not be fully controlled and from the reaction mixture both $\mathrm{R}_{2} \mathrm{SbF}$ and $\mathrm{RSbF}_{2}$ were isolated by fractional crystallization, e.g. for $\mathrm{R}=2,4,6-{ }^{t} \mathrm{Bu}_{3} \mathrm{C}_{6} \mathrm{H}_{2} \cdot{ }^{11,12}$

Taking into account the ability of the organoantimony(v) cations to react with the fluoride anions we have decided to investigate the possibility to prepare diorganoantimony(III) fluorides using ionic species such as the diorganoantimony(III) cation, $\left[\mathrm{R}_{2} \mathrm{Sb}\right]^{+}$. Monocations of this type can be stabilized by 
intermolecular ${ }^{19-24}$ coordination, e.g. $\left[\mathrm{Ph}_{2} \mathrm{Sb}\left\{\mathrm{OP}\left(\mathrm{NMe}_{2}\right)_{3}\right\}_{2}\right]^{+}\left[\mathrm{PF}_{6}\right]^{-19}$ $\left[\mathrm{Me}_{2} \mathrm{Sb}\left(\mathrm{SbMe}_{3}\right)\right]^{+}\left[\mathrm{GaCl}_{4}\right]^{-},{ }^{21} \quad\left[\mathrm{Ph}_{2} \mathrm{Sb}\left(\mathrm{PPh}_{3}\right)_{2}\right]^{+}\left[\mathrm{PF}_{6}\right]^{-, 23} \quad\left[\mathrm{Ph}_{2} \mathrm{Sb}\left(\mathrm{PMe}_{3}\right]^{+}\right.$ $\left[\mathrm{O}_{3} \mathrm{SCF}_{3}\right]^{-}$and $\left[\mathrm{Ph}_{2} \mathrm{Sb}\left(\mathrm{PMe}_{3}\right)_{2}\right]^{+}\left[\mathrm{O}_{3} \mathrm{SCF}_{3}\right]^{-, 24}$ or by intramolecular coordination, e.g. $\left[\left\{2-\left(\mathrm{Me}_{2} \mathrm{NCH}_{2}\right) \mathrm{C}_{6} \mathrm{H}_{4}\right\}_{2} \mathrm{Sb}\right]^{+}\left[\mathrm{PF}_{6}\right]^{-},{ }^{19}$ and $[\{2,6-$ $\left.\left.\left(\mathrm{MeOCH}_{2}\right)_{2} \mathrm{C}_{6} \mathrm{H}_{3}\right\}_{2} \mathrm{Sb}\right]_{4}^{+}\left[\mathrm{Sb}_{6} \mathrm{Cl}_{22}\right]^{4-} .{ }^{25}$

We report herein a new route for the preparation of the diorganoantimony(III) fluorides via ionic diorganoantimony(III) derivatives stabilized by $(C, N)$-chelating ligands as well as their structural characterization both in solution and in the solid state.

\section{Results and discussion}

\section{Synthesis and characterization of ionic diorganoantimony(III) compounds}

The monohalides $\mathrm{R}_{2} \mathrm{SbBr}$, (R) $\mathrm{PhSbCl}\left[\mathrm{R}=2-\left(2^{\prime}, 6^{\prime}-{ }^{\mathrm{i}} \mathrm{Pr}_{2} \mathrm{C}_{6} \mathrm{H}_{3} \mathrm{~N}=\right.\right.$ $\left.\mathrm{CH}) \mathrm{C}_{6} \mathrm{H}_{4}\right]$ and $\mathrm{R}_{2}^{\prime} \mathrm{SbBr}\left[\mathrm{R}^{\prime}=2-\left(2^{\prime}, 4^{\prime}, 6^{\prime}-\mathrm{Me}_{3} \mathrm{C}_{6} \mathrm{H}_{2} \mathrm{~N}=\mathrm{CH}\right) \mathrm{C}_{6} \mathrm{H}_{4}\right]$ were reacted with $\mathrm{Tl}\left[\mathrm{PF}_{6}\right]$ in THF, at room temperature, to give the ionic diorganoantimony(III) species $\left[\left\{2-\left(2^{\prime}, 6^{\prime}-{ }^{\mathrm{i}} \mathrm{Pr}_{2} \mathrm{C}_{6} \mathrm{H}_{3} \mathrm{~N}=\mathrm{CH}\right)\right.\right.$ $\left.\left.\mathrm{C}_{6} \mathrm{H}_{4}\right\}_{2} \mathrm{Sb}\right]^{+}\left[\mathrm{PF}_{6}\right]^{-}(\mathbf{1}),\left[\left\{2-\left(2^{\prime}, 6^{\prime}-{ }^{\mathrm{i}} \mathrm{Pr}_{2} \mathrm{C}_{6} \mathrm{H}_{3} \mathrm{~N}=\mathrm{CH}\right) \mathrm{C}_{6} \mathrm{H}_{4}\right\} \mathrm{PhSb}\right]^{+}\left[\mathrm{PF}_{6}\right]^{-}$ (2) and $\left[\left\{2-\left(2^{\prime}, 4^{\prime}, 6^{\prime}-\mathrm{Me}_{3} \mathrm{C}_{6} \mathrm{H}_{2} \mathrm{~N}=\mathrm{CH}\right) \mathrm{C}_{6} \mathrm{H}_{4}\right\}_{2} \mathrm{Sb}^{+}\left[\mathrm{PF}_{6}\right]^{-}\right.$(3) (Scheme 1).

Using a similar procedure, treatment of the monochloride $\mathrm{R}_{2}{ }_{2} \mathrm{SbCl}\left[\mathrm{R}^{\prime \prime}=2-\left(\mathrm{Me}_{2} \mathrm{NCH}_{2}\right) \mathrm{C}_{6} \mathrm{H}_{4}\right]$ with $\mathrm{Ag}\left[\mathrm{SbF}_{6}\right]$ gave the ionic compound $\left[\left\{2-\left(\mathrm{Me}_{2} \mathrm{NCH}_{2}\right) \mathrm{C}_{6} \mathrm{H}_{4}\right\}_{2} \mathrm{Sb}^{+}\left[\mathrm{SbF}_{6}\right]^{-}\right.$(4) (Scheme 2). The species $\left[\left\{2-\left(\mathrm{Me}_{2} \mathrm{NCH}_{2}\right) \mathrm{C}_{6} \mathrm{H}_{4}\right\} \mathrm{PhSb}\right]^{+}\left[\mathrm{SbF}_{6}\right]^{-}$was prepared in situ from the corresponding monochloride $\left(\mathrm{R}^{\prime \prime}\right) \mathrm{PhSbCl}$ and $\mathrm{Ag}\left[\mathrm{SbF}_{6}\right]$ and converted, without isolation, into the fluoride $\mathbf{8}$ (Scheme 2).

The compounds were isolated in fair good yields as pale yellow $(\mathbf{1}, \mathbf{2}, 3)$ and white (4) solids, soluble in chlorinated solvents. The spectroscopic data as well as elemental analytical data are consistent with the anticipated formulas. For compounds 1-3 the IR spectra exhibit a $\nu(\mathrm{CH}=\mathrm{N})$ stretching

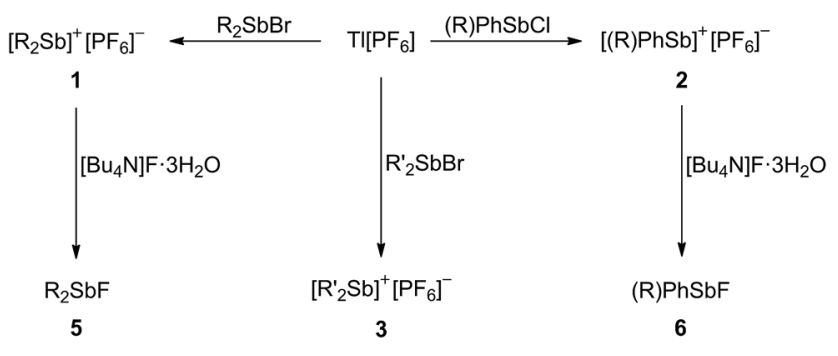

$\mathrm{R}=2-\left(2^{\prime}, 6^{\prime}-\mathrm{Pr}_{2} \mathrm{C}_{6} \mathrm{H}_{3} \mathrm{~N}=\mathrm{CH}\right) \mathrm{C}_{6} \mathrm{H}_{4} ; \quad \mathrm{R}^{\prime}=2-\left(2^{\prime}, 4^{\prime}, 6^{\prime}-\mathrm{Me}_{3} \mathrm{C}_{6} \mathrm{H}_{2} \mathrm{~N}=\mathrm{CH}\right) \mathrm{C}_{6} \mathrm{H}_{4}$

Scheme 1 Preparation of the ionic species 1-3 and the fluorides 5 and 6 .

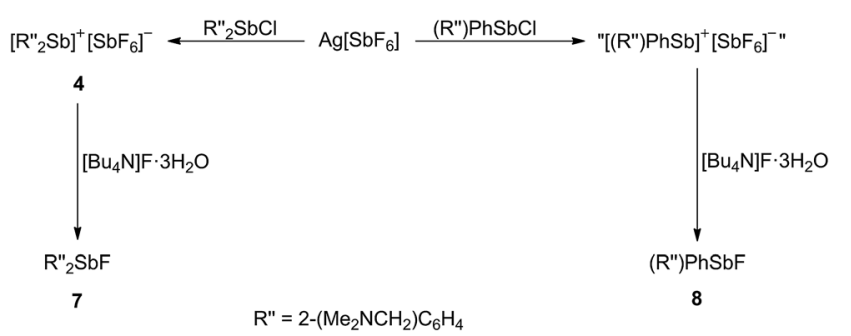

Scheme 2 Preparation of the ionic species 4 and the fluorides 7 and 8 . vibration of medium intensity in the region $1620-1600 \mathrm{~cm}^{-1}$, which is typical for compounds containing Schiff-base ligands. ${ }^{18}$ In addition, strong $\nu(\mathrm{E}-\mathrm{F})$ stretching vibrations corresponding to the inorganic $\left[\mathrm{EF}_{6}\right]^{-}$anions were observed, as expected ${ }^{26}$ in the regions $835-800 \mathrm{~cm}^{-1}(\mathrm{E}=\mathrm{P})$ for compounds 1-3 and around $750 \mathrm{~cm}^{-1}(\mathrm{E}=\mathrm{Sb})$ for compound 4 . In the ESI $(+)$ (for 1, 3, 4) and $\mathrm{APCI}(+)$ (for 2) mass spectra the base peaks were assigned to the corresponding fragments $\left[\mathrm{R}_{2} \mathrm{Sb}^{+}\right],\left[\mathrm{R}_{2}^{\prime} \mathrm{Sb}^{+}\right]$and $\left[\mathrm{R}_{2}{ }_{2} \mathrm{Sb}^{+}\right]$, and $\left[\mathrm{RPhSb}^{+}\right]$, respectively.

All ionic compounds were investigated by multinuclear NMR spectroscopy in $\mathrm{CDCl}_{3}$ solution, at room temperature. The assignment of the resonances was based on 2D NMR spectra, according with the numbering schemes illustrated in Scheme S1 (see ESI $\dagger$ ). The ${ }^{1} \mathrm{H}$ NMR spectra of 1 and 2 exhibit four doublet resonances for the methyl protons. This indicates a diastereotopic behaviour of the isopropyl groups as well as non-equivalence of the two halves of a $2^{\prime}, 6^{\prime}-{ }^{\mathrm{i}} \mathrm{Pr}_{2} \mathrm{C}_{6} \mathrm{H}_{3}$ moiety, the free rotation of the bulky aromatic group around the $\mathrm{C}-\mathrm{N}(=\mathrm{C})$ single bond being blocked. This is also supported, for example, by the presence of two singlet resonances for the methine $\mathrm{C}-7^{\prime}{ }_{\mathrm{a}}$ and C-7 ${ }^{\prime}$ atoms in the ${ }^{13} \mathrm{C}$ NMR spectra $(\delta 30.21$ and $28.96 \mathrm{ppm}$ for 1 and $\delta 29.15$ and $28.13 \mathrm{ppm}$ for 2 , respectively). By contrast, for the cation of 3 both ${ }^{1} \mathrm{H}$ and ${ }^{13} \mathrm{C}$ NMR spectra exhibit only two sharp resonances assigned to the methyl protons $1: 2$ integral ration) of the $2^{\prime}, 4^{\prime}, 6^{\prime}-\mathrm{Me}_{3} \mathrm{C}_{6} \mathrm{H}_{2}$ moieties attached to the metal atom, suggesting that there is no restriction of free rotation of the mesityl groups around the $\mathrm{C}-\mathrm{N}(=\mathrm{C})$ single bonds. This different freedom of rotation around a $\mathrm{C}-\mathrm{N}(=\mathrm{C})$ single bond observed for compounds $\mathbf{1}$ (or 2) and 3, respectively, in $\mathrm{CDCl}_{3}$ solution at room temperature, is related to the bulkiness of the organic group attached to nitrogen. The presence of only one set of resonances in the ${ }^{1} \mathrm{H}$ and ${ }^{13} \mathrm{C}$ NMR spectra for the two organic groups in the cations of $\mathbf{1}, \mathbf{3}$ and $\mathbf{4}$ is consistent with equivalence of the aromatic ligands attached to the same metal atom. The room temperature ${ }^{1} \mathrm{H}$ and ${ }^{13} \mathrm{C}$ NMR spectra of $\mathbf{4}$ show one set of singlet resonances for the methyl and methylene groups, respectively, suggesting a fast dynamic behaviour which involves de-coordination - re-coordination of nitrogen to the metal centre. The presence of the octahedral fluorinecontaining anions is indicated by the doublet ${ }^{19} \mathrm{~F}$ resonance $\left({ }^{1} J_{\mathrm{P}, \mathrm{F}}=713 \mathrm{~Hz}\right)$ observed for compounds 1-3 and the multiplet ${ }^{19} \mathrm{~F}$ resonance observed for compound 4 . Consequently, the ${ }^{31} \mathrm{P}$ NMR spectra of 1-3 exhibit a septet resonance centered at $\delta-144 \mathrm{ppm}$.

Single crystals of $\mathbf{1} \cdot 2 \mathrm{CH}_{2} \mathrm{Cl}_{2}$ and $3 \cdot 2 \mathrm{CHCl}_{3}$ were investigated by X-ray diffraction. The crystals contain the corresponding diorganoantimony(III) cations and hexafluorophosphate anions. The structure of the cations of $\mathbf{1}$ and $\mathbf{3}$ are depicted in Fig. 1 and $\mathrm{S} 5, \dagger$ respectively, and the important bond lengths and angles are listed in Table 1.

In the cations of $\mathbf{1}$ and 3 both nitrogen atoms are coordinated to antimony in an almost trans arrangement [N(1)- $\mathrm{Sb}(1)-$ $\mathrm{N}(2) 159.67(10)^{\circ}$ for 1 ; $155.02(17)^{\circ}$ for 3 ] resulting in a pseudotrigonal bipyramidal ("see-saw") coordination geometry at antimony, with the ipso carbon atoms placed in equatorial positions [C(1)-Sb(1)-C(20) $105.05(14)^{\circ}$ for 1 ; $\mathrm{C}(1)-\mathrm{Sb}(1)-\mathrm{C}(17)$ $102.8(2)^{\circ}$ for 3]. The antimony-nitrogen bond distances [Sb-N 


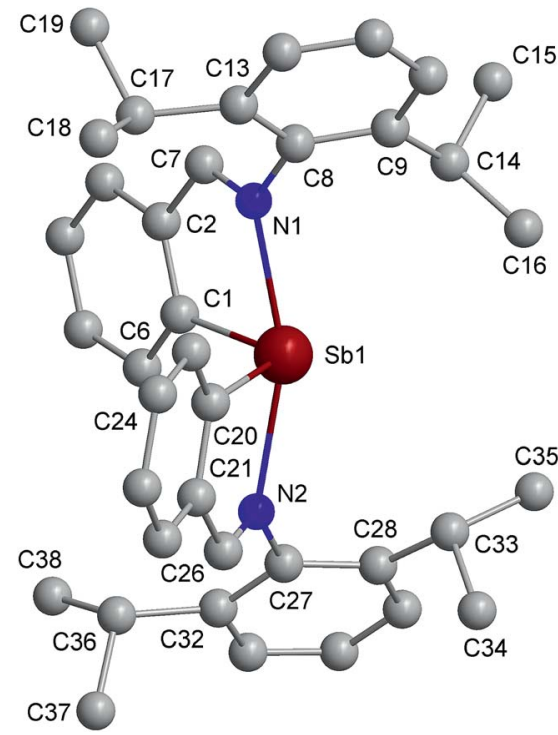

Fig. 1 Structure of the $(\Lambda)$-cation in $1 \cdot 2 \mathrm{CH}_{2} \mathrm{Cl}_{2}$, showing the atom numbering scheme. Hydrogen atoms are omitted for clarity.

Table 1 Selected bond distances $(\AA)$ and angles $\left(^{\circ}\right)$ for compounds $1 \cdot 2 \mathrm{CH}_{2} \mathrm{Cl}_{2}$ and $3 \cdot 2 \mathrm{CHCl}_{3}$

\begin{tabular}{llll}
\hline $\mathbf{1} \cdot 2 \mathrm{CH}_{2} \mathrm{Cl}_{2}$ & & $3 \cdot 2 \mathrm{CHCl}_{3}$ & \\
\hline $\mathrm{Sb}(1)-\mathrm{C}(1)$ & $2.145(4)$ & $\mathrm{Sb}(1)-\mathrm{C}(1)$ & $2.167(6)$ \\
$\mathrm{Sb}(1)-\mathrm{C}(20)$ & $2.131(4)$ & $\mathrm{Sb}(1)-\mathrm{C}(17)$ & $2.151(5)$ \\
$\mathrm{Sb}(1)-\mathrm{N}(1)$ & $2.353(3)$ & $\mathrm{Sb}(1)-\mathrm{N}(1)$ & $2.365(5)$ \\
$\mathrm{Sb}(1)-\mathrm{N}(2)$ & $2.367(3)$ & $\mathrm{Sb}(1)-\mathrm{N}(2)$ & $2.395(5)$ \\
$\mathrm{N}(1)-\mathrm{C}(7)$ & $1.276(5)$ & $\mathrm{N}(1)-\mathrm{C}(7)$ & $1.269(9)$ \\
$\mathrm{N}(1)-\mathrm{C}(8)$ & $1.450(5)$ & $\mathrm{N}(1)-\mathrm{C}(8)$ & $1.442(8)$ \\
$\mathrm{N}(2)-\mathrm{C}(26)$ & $1.285(5)$ & $\mathrm{N}(2)-\mathrm{C}(23)$ & $1.267(7)$ \\
$\mathrm{N}(2)-\mathrm{C}(27)$ & $1.446(5)$ & $\mathrm{N}(2)-\mathrm{C}(24)$ & $1.435(7)$ \\
$\mathrm{C}(1)-\mathrm{Sb}(1)-\mathrm{C}(20)$ & $105.05(14)$ & $\mathrm{C}(1)-\mathrm{Sb}(1)-\mathrm{C}(17)$ & $102.8(2)$ \\
$\mathrm{N}(1)-\mathrm{Sb}(1)-\mathrm{N}(2)$ & $159.67(10)$ & $\mathrm{N}(1)-\mathrm{Sb}(1)-\mathrm{N}(2)$ & $155.02(17)$ \\
$\mathrm{N}(1)-\mathrm{Sb}(1)-\mathrm{C}(1)$ & $75.70(12)$ & $\mathrm{N}(1)-\mathrm{Sb}(1)-\mathrm{C}(1)$ & $75.16(19)$ \\
$\mathrm{N}(1)-\mathrm{Sb}(1)-\mathrm{C}(20)$ & $92.23(12)$ & $\mathrm{N}(1)-\mathrm{Sb}(1)-\mathrm{C}(17)$ & $89.21(19)$ \\
$\mathrm{N}(2)-\mathrm{Sb}(1)-\mathrm{C}(1)$ & $91.70(12)$ & $\mathrm{N}(2)-\mathrm{Sb}(1)-\mathrm{C}(1)$ & $89.2(2)$ \\
$\mathrm{N}(2)-\mathrm{Sb}(1)-\mathrm{C}(20)$ & $75.46(12)$ & $\mathrm{N}(2)-\mathrm{Sb}(1)-\mathrm{C}(17)$ & $75.21(18)$ \\
& & &
\end{tabular}

2.353(3)/2.367(3) ̊̊ for $1 ; 2.365(5) / 2.395(5) \AA$ for 3] compare well with those found in the related ionic species $\left[\left\{2-\left(\mathrm{Me}_{2} \mathrm{NCH}_{2}\right)\right.\right.$ $\left.\left.\mathrm{C}_{6} \mathrm{H}_{4}\right\}_{2} \mathrm{Sb}\right]^{+}\left[\mathrm{PF}_{6}\right]^{-}[\mathrm{Sb}-\mathrm{N}$ 2.412(3)/2.416(4) $\left.\AA]\right]^{19}$ but are shorter than in the bromide precursor $\left[2-\left\{\left(2^{\prime}, 6^{\prime}-{ }^{\mathrm{i}} \mathrm{Pr}_{2} \mathrm{C}_{6} \mathrm{H}_{3}\right) \mathrm{N}=\mathrm{CH}\right\}\right.$ $\left.\mathrm{C}_{6} \mathrm{H}_{4}\right]_{2} \mathrm{SbBr}[\mathrm{Sb}-\mathrm{N} 2.498(4) / 2.996(4) \AA]^{18}[c f$. sums of the corresponding covalent, $\Sigma r_{\text {cov }}(\mathrm{Sb}, \mathrm{N}) 2.11 \AA$, and van der Waals radii, $\left.\Sigma r_{\mathrm{vdw}}(\mathrm{Sb}, \mathrm{N}) 3.74 \AA\right],{ }^{27}$ due to the more electrophilic nature of the antimony in the cation.

The cations of both these ionic species exhibit a helical structure due to the $(C, N)$-chelating ligands. The corresponding configurations at the metal can be given as $\Delta_{\mathrm{Sb}}\left(\right.$ or $\left.P_{\mathrm{Sb}}\right)$ and $\Lambda_{\mathrm{Sb}}$ (or $M_{\mathrm{Sb}}$ ) with respect to the right-handed or left-handed helicity of the two chelate rings along the $C_{2}$-axis passing through the centre of the $\mathrm{C} \cdots \mathrm{C}$ edge (carbon atoms attached to antimony), the metal ion and the centre of the $\mathrm{N} \cdots \mathrm{N}$ edge. ${ }^{28}$ Both compounds 1 and 3 crystallize as a $1: 1$ mixture of $\left(\Delta_{\mathrm{Sb}}\right)$ - and $\left(\Lambda_{\mathrm{Sb}}\right)$-cations. No cation-anion interactions between heavy atoms were observed. However, for both compounds supramolecular associations are built through halogen $\cdots$ hydrogen and $\mathrm{C}-\mathrm{H} \cdots \pi$ ( $\left.\mathrm{Ar}_{\text {centroid }}\right)$ interactions. Thus, in the crystal of $\mathbf{1} \cdot 2 \mathrm{CH}_{2} \mathrm{Cl}_{2}$ chain polymers are formed based on $\mathrm{F} \cdot \mathrm{H}_{\text {imine }}$ contacts between anions and $\left(\Delta_{\mathrm{Sb}}\right)$ - or $\left(\Lambda_{\mathrm{Sb}}\right)$-cations (see Fig. S3, ESI $\uparrow$ ). Alternating, parallel, polymeric chains containing $\left(\Delta_{\mathrm{Sb}}\right)-$ and $\left(\Lambda_{\mathrm{Sb}}\right)$-cations, respectively, are connected through $\mathrm{Cl}_{\text {solvent }}{ }^{\cdots \mathrm{H}}$ contacts into a layer (see Fig. S4, ESI $\dagger$ ). By contrast, in the crystal of $3 \cdot 2 \mathrm{CHCl}_{3}$ centrosymmetric dinuclear units are formed from $\left(\Delta_{\mathrm{Sb}}\right)$ - and $\left(\Lambda_{\mathrm{Sb}}\right)$-cations based on $\mathrm{C}-\mathrm{H}_{\text {methyl }} \cdots \pi$ $\left(\mathrm{Ar}_{\text {centroid }}\right)$ interactions (i.e. $\mathrm{H} \cdots \mathrm{Ar}_{\text {centroid }}$ contacts shorter than $3.1 \AA$, with an angle $\gamma$ between the normal to the aromatic ring and the line defined by the $\mathrm{H}$ atom and $\mathrm{Ar}_{\text {centroid smaller }}$ than $\left.30^{\circ}\right):{ }^{29} \mathrm{C}(16)-\mathrm{H}(16 \mathrm{~B})_{\text {methyl }} \cdots \mathrm{Ar}_{\text {centroid }}\left\{\mathrm{C}\left(24^{\prime}\right)-\mathrm{C}\left(29^{\prime}\right)\right\} 2.85 \AA$ $\left(\gamma=3.8^{\circ}\right)$. These dinuclear units are further connected through anions and solvent molecules into chain polymers (see Fig. S8, ESI $\dagger$ ). In the crystals there are no further contacts between parallel layers (for $\mathbf{1} \cdot 2 \mathrm{CH}_{2} \mathrm{Cl}_{2}$ ) or polymeric chains (for $\left.3 \cdot 2 \mathrm{CHCl}_{3}\right)$.

\section{Synthesis and characterization of diorganoantimony(III) fluorides}

The treatment of the ionic compounds $\mathbf{1}, \mathbf{2}, \mathbf{4}$ and [ $\{2-$ $\left.\left.\left(\mathrm{Me}_{2} \mathrm{NCH}_{2}\right) \mathrm{C}_{6} \mathrm{H}_{4}\right\} \mathrm{PhSb}\right]^{+}\left[\mathrm{SbF}_{6}\right]^{-}$with $\left[\mathrm{Bu}_{4} \mathrm{~N}\right] \mathrm{F} \cdot 3 \mathrm{H}_{2} \mathrm{O}$ in acetonitrile, at room temperature, followed by extraction with $n$-hexane leads to the isolation of the organoantimony(III) fluorides: [2$\left.\left(2^{\prime}, 6^{\prime}-{ }^{\mathrm{i}} \mathrm{Pr}_{2} \mathrm{C}_{6} \mathrm{H}_{3} \mathrm{~N}=\mathrm{CH}\right) \mathrm{C}_{6} \mathrm{H}_{4}\right]_{2} \mathrm{SbF} \quad(5), \quad\left[2-\left(2^{\prime}, 6^{\prime}-{ }^{\mathrm{i}} \mathrm{Pr}_{2} \mathrm{C}_{6} \mathrm{H}_{3} \mathrm{~N}=\mathrm{CH}\right)\right.$ $\left.\mathrm{C}_{6} \mathrm{H}_{4}\right] \mathrm{PhSbF}$ (6) (Scheme 1), [2-( $\left.\left.\mathrm{Me}_{2} \mathrm{NCH}_{2}\right) \mathrm{C}_{6} \mathrm{H}_{4}\right]_{2} \mathrm{SbF}$ (7) and [2$\left.\left(\mathrm{Me}_{2} \mathrm{NCH}_{2}\right) \mathrm{C}_{6} \mathrm{H}_{4}\right] \mathrm{PhSbF}$ (8) (Scheme 2). The fluorides were obtained as air-stable, yellow $(\mathbf{5}, \mathbf{6})$ or white $(7, \mathbf{8})$ solids. They are easily soluble in chlorinated organic solvents as $\mathrm{CHCl}_{3}$, a behaviour consistent with their molecular structure observed in solid state. In the case of fluorides $\mathbf{5}$ and $\mathbf{6}$ an absorption band was observed at 1641 and $1622 \mathrm{~cm}^{-1}$, respectively, which was assigned to the $\nu_{\mathrm{CH}=\mathrm{N}}$ stretching vibration, consistent with the presence of the imine ligand. In the $\operatorname{ESI}(+)$ (for 5, 7 and 8) and $\mathrm{APCI}(+)$ (for 6) mass spectra the base peaks were assigned to the corresponding fragments $\left[\mathrm{R}_{2} \mathrm{Sb}^{+}\right],\left[\mathrm{R}^{\prime \prime}{ }_{2} \mathrm{Sb}^{+}\right],\left[\mathrm{R}^{\prime \prime} \mathrm{PhSb}{ }^{+}\right]$, and $\left[\mathrm{RPhSb}^{+}\right]$, respectively. The mass spectrum of 6 showed a fragment with $\mathrm{m} / \mathrm{z}$ value (i.e. 945) higher than that corresponding to the molecular ion, which was assigned to the dinuclear cation containing fluorine bridge between metal atoms, $\left[(\mathrm{RPhSb})_{2} \mathrm{~F}^{+}\right]$.

The ${ }^{19} \mathrm{~F}$ NMR spectra of the new fluorides exhibit a sharp singlet resonance at $\delta-181.3,-174.7,-176.9$ and $-169.2 \mathrm{ppm}$ (for 5, 6, 7 and 8, respectively), a behaviour consistent with the presence of only one species in the solution of these compounds. The structure of the fluorides $\mathbf{5 - 8}$ in $\mathrm{CDCl}_{3}$ solutions was investigated by ${ }^{1} \mathrm{H}$ and ${ }^{13} \mathrm{C}$ NMR spectroscopy at room temperature. The assignment of the observed resonances, according with the numbering schemes illustrated in Scheme S1 (see ESI $\dagger$ ), was based on 2D NMR spectra. For the fluoride 5, the NMR spectra at room temperature are consistent with a similar behaviour as observed previously for the analogous chloride ${ }^{30}$ and bromide, ${ }^{18}$ i.e. the presence in the same molecule of one organic ligand for which the free rotation around the $\mathrm{C}-\mathrm{N}(=\mathrm{C})$ single bond is blocked (non-equivalence of the two 
halves of a $2^{\prime}, 6^{\prime}-{ }^{\mathrm{i}} \mathrm{Pr}_{2} \mathrm{C}_{6} \mathrm{H}_{3}$ moiety) and one organic ligand with no restriction of free rotation around the $\mathrm{C}-\mathrm{N}(=\mathrm{C})$ single bond. A similar restricted rotation around the $\mathrm{C}-\mathrm{N}(=\mathrm{C})$ single bond was observed for the imine ligand in $\mathbf{6}$, at room temperature. This is consistent with four doublet ${ }^{1} \mathrm{H}$ resonances for the methyl protons and two septet resonances for the methine protons of the ${ }^{\mathrm{i}} \mathrm{Pr}$ groups indicating that the two halves of the $2^{\prime}, 6^{\prime}-{ }^{\mathrm{i}} \mathrm{Pr}_{2}-$ $\mathrm{C}_{6} \mathrm{H}_{3}$ moiety are not equivalent. The NMR spectra of fluorides 7 and $\mathbf{8}$ are consistent with the expected structures. For 7 only one set of resonances was observed suggesting a dynamic behaviour which results in equivalent organic ligands on the NMR time scale, at room temperature. The fluoride $\mathbf{8}$, with different organic groups attached to antimony, exhibits two singlet ${ }^{1} \mathrm{H}$ resonances, a behaviour consistent with the presence of intramolecular $\mathrm{N} \rightarrow \mathrm{Sb}$ interaction in solution. Interesting, an evident $\mathrm{AB}$ system was not observed for the $\mathrm{CH}_{2}$ group of the pendant arm due to isochronous chemical shifts of the methylene protons. It should be also noted that for several carbon atoms the corresponding resonances appear as doublets due to carbon-fluorine couplings at two or even three bond distances.

Single crystals of the diorganoantimony(III) fluorides 5-8, suitable for X-ray diffraction studies, were obtained by slow evaporation of their $n$-hexane solutions. The molecular structures are depicted in Fig. 2, 3, S20 and S24. $\dagger$ Selected bond lengths and angles are listed in Table 2.

The crystals of all four fluorides 5-8 contain discrete molecules with no intermolecular contacts between heavy atoms. This contrasts with the chain polymeric structure of $\mathrm{Ph}_{2} \mathrm{SbF}$ in which molecular units are connected by strong, almost symmetric $\mathrm{Sb}-\mathrm{F} \cdots \mathrm{Sb}$ bridges. ${ }^{8}$ As a consequence, the terminal antimony-fluorine bond distances in the title fluorides [ $\mathrm{Sb}(1)-$ $\mathrm{F}$ (1) 1.997(5) $\AA$ in 5, 1.9989(19) $\AA$ in 6, 2.032(4) $\AA$ in 7 and 2.001(2) $\AA$ in 8, respectively] are shorter than those found in the unique polymeric monofluoride $\mathrm{Ph}_{2} \mathrm{SbF}$ [intramolecular $\mathrm{Sb}-\mathrm{F}$

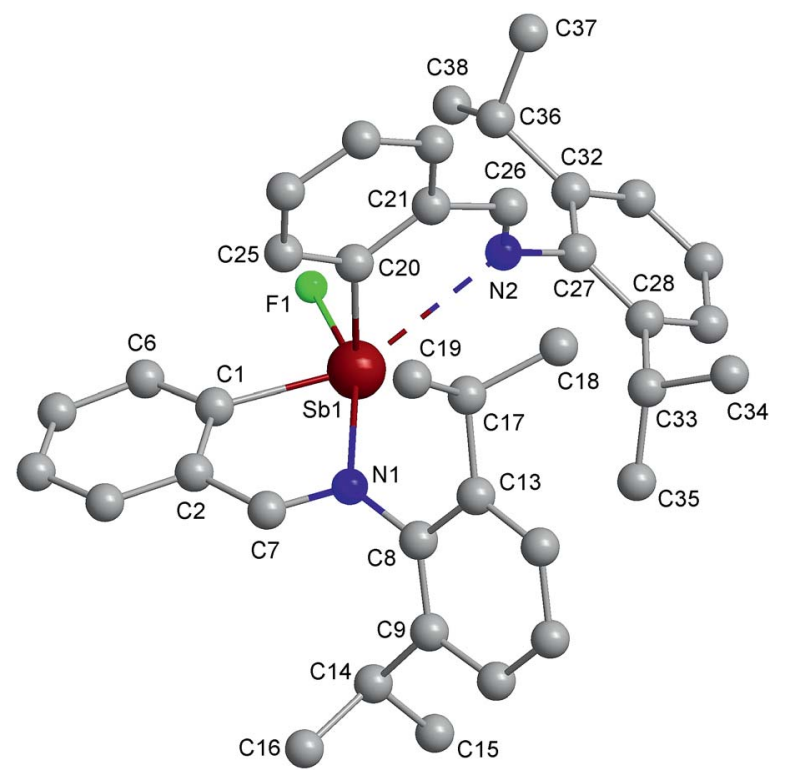

Fig. 2 Molecular structure of $\left(C_{\mathrm{Sb}}\right)-5$, showing the atom numbering scheme. Hydrogen atoms are omitted for clarity.

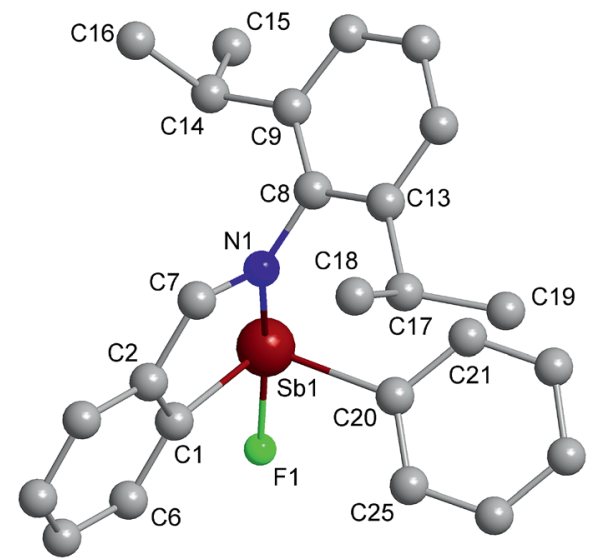

Fig. 3 Molecular structure of $\left(C_{S b}\right)-6$, showing the atom numbering scheme. Hydrogen atoms are omitted for clarity.

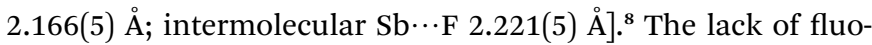
rine bridges in the case of the fluorides 5-8 is the result of intramolecular coordination of the nitrogen atom from the pendant arm to the metal centre.

Indeed, in the molecules of 5 and 7, which contain two similar organic ligands with one pendant arm, both nitrogen atoms are coordinated intramolecularly to antimony. As expected, one nitrogen atom is strongly coordinated to the metal [Sb(1)-N(1) 2.693(6) A in 5, and 2.512(5) A in 7] in trans position to the fluorine atom $\left[\mathrm{F}(1)-\mathrm{Sb}(1)-\mathrm{N}(1) \quad 158.66(18)^{\circ}\right.$ in $\mathbf{5}$, and $161.74(16)^{\circ}$ in 7]. Due to a stronger trans influence of the fluorine atom these $\mathrm{N} \rightarrow \mathrm{Sb}$ distances are considerably longer for both 5 and 7 than observed in the related chlorides/bromides/ iodides, i.e. $\left[2-\left(2^{\prime}, 6^{\prime}-{ }^{\mathrm{i}} \mathrm{Pr}_{2} \mathrm{C}_{6} \mathrm{H}_{3} \mathrm{~N}=\mathrm{CH}\right) \mathrm{C}_{6} \mathrm{H}_{4}\right]_{2} \mathrm{SbX}[\mathrm{Sb}-\mathrm{N}$ 2.416(2) $\AA$ for $\mathrm{X}=\mathrm{Cl} ;{ }^{30} 2.498(4) \AA$ for $\left.\mathrm{X}=\mathrm{Br}^{18}\right]$ or $\left[2-\left(\mathrm{Me}_{2} \mathrm{NCH}_{2}\right) \mathrm{C}_{6} \mathrm{H}_{4}\right]_{2} \mathrm{SbX}$ $\left[\mathrm{Sb}-\mathrm{N} 2.463(2) \AA\right.$ for $\mathrm{X}=\mathrm{Cl} ;{ }^{31} 2.423(3) \AA$ for $\mathrm{X}=\mathrm{Br}$; 2.417(3) $\mathrm{A}$ for $\left.\mathrm{X}=\mathrm{I}^{17}\right]$. The nitrogen atom of the second pendant arm in the molecule is placed in trans position to an ipso carbon atom and exhibits a slightly longer intramolecular bond in 5 [Sb(1)-N(2) 2.778(7) $\AA$; $\left.\mathrm{N}(2)-\mathrm{Sb}(1)-\mathrm{C}(1) 156.1(3)^{\circ}\right]$, but being considerably longer in 7 [Sb(1)-N(2) 3.379(6) ̊; N(2)-Sb(1)-C(1) 154.30(17) ${ }^{\circ}$; $c f$. sums of the respective covalent, $\Sigma r_{\text {cov }}(\mathrm{Sb}, \mathrm{N}) 2.11 \AA$, and van der Waals radii, $\left.\Sigma r_{\mathrm{vdw}}(\mathrm{Sb}, \mathrm{N}) 3.74 \AA \mathrm{A}\right]{ }^{27}$ While for the fluoride 7 the length of the $\mathrm{N} \rightarrow \mathrm{Sb}$ bond placed in trans position to the carbon atom is similar to those observed for the other analogous halides $\left[c f\right.$. Sb-N 3.216(3) $\AA$ for $\mathrm{X}=\mathrm{Cl} ;^{31} 3.276(3) \AA$ for $\mathrm{X}=\mathrm{Br}$; 3.211(3) $\mathrm{A}$ for $\mathrm{X}=\mathrm{I}^{17}$, for the imine derivative 5 this $\mathrm{N} \rightarrow$ Sb distance is considerably shorter than in the corresponding chloride or bromide [Sb-N 2.952(3) $\AA$ for $\mathrm{X}=\mathrm{Cl}^{30}{ }^{30} 2.996(4) \AA$ for $\left.\mathrm{X}=\mathrm{Br}^{18}\right]$.

In the molecules of the chiral fluorides $\mathbf{6}$ and 8 , which contain one phenyl group and one organic ligand of the same type as in $\mathbf{5}$ and 7, again the nitrogen atom of the pendant arm is strongly coordinated to the metal atom $[\mathrm{Sb}(1)-\mathrm{N}(1) 2.466(3) \AA$ in 6, and 2.526(3) $\AA$ in 8] in trans position to the fluorine atom $\left[\mathrm{F}(1)-\mathrm{Sb}(1)-\mathrm{N}(1) \quad 158.97(8)^{\circ}\right.$ in $\mathbf{6}$, and $161.48(9)^{\circ}$ in 8]. The intramolecular $\mathrm{N} \rightarrow \mathrm{Sb}$ bond distance is longer than found in the related halides i.e. $\left[2-\left(2^{\prime}, 6^{\prime}-{ }^{\mathrm{i}} \mathrm{Pr}_{2} \mathrm{C}_{6} \mathrm{H}_{3} \mathrm{~N}=\mathrm{CH}\right) \mathrm{C}_{6} \mathrm{H}_{4}\right]_{2} \mathrm{SbX}[\mathrm{Sb}-$ $\mathrm{N} 2.433(2) \AA]^{32}$ or $\left[2-\left(\mathrm{Me}_{2} \mathrm{NCH}_{2}\right) \mathrm{C}_{6} \mathrm{H}_{4}\right] \mathrm{PhSbX}[\mathrm{Sb}-\mathrm{N} 2.452(2) \AA$ for $\mathrm{X}=\mathrm{Cl} ;^{33} 2.444(4) \AA$ for $\mathrm{X}=\mathrm{Br} ; 2.426(3) \AA$ for $\left.\mathrm{X}=\mathrm{I}^{34}\right]$. 
Table 2 Selected bond distances $(\AA \AA)$ and angles $\left({ }^{\circ}\right)$ for compounds 5-8

\begin{tabular}{|c|c|c|c|c|c|}
\hline & 5 & 6 & & 7 & 8 \\
\hline $\mathrm{Sb}(1)-\mathrm{C}(1)$ & $2.172(7)$ & $2.128(3)$ & $\mathrm{Sb}(1)-\mathrm{C}(1)$ & $2.134(6)$ & $2.141(3)$ \\
\hline $\mathrm{Sb}(1)-\mathrm{C}(20)$ & $2.172(8)$ & $2.122(3)$ & $\mathrm{Sb}(1)-\mathrm{C}(10)$ & $2.151(5)$ & $2.150(3)$ \\
\hline $\mathrm{Sb}(1)-\mathrm{N}(1)$ & $2.693(6)$ & $2.466(3)$ & $\mathrm{Sb}(1)-\mathrm{N}(1)$ & $2.512(5)$ & $2.526(3)$ \\
\hline $\mathrm{Sb}(1)-\mathrm{N}(2)$ & $2.778(7)$ & & $\mathrm{Sb}(1)-\mathrm{N}(2)$ & $3.379(6)$ & \\
\hline$N(1)-C(7)$ & $1.268(11)$ & $1.269(4)$ & $\mathrm{N}(1)-\mathrm{C}(7)$ & $1.466(8)$ & $1.464(4)$ \\
\hline$N(2)-C(26)$ & $1.264(11)$ & & $\mathrm{N}(2)-\mathrm{C}(16)$ & $1.450(9)$ & \\
\hline \multirow[t]{2}{*}{$\mathrm{N}(2)-\mathrm{C}(27)$} & $1.439(11)$ & & $N(2)-C(17)$ & $1.442(11)$ & \\
\hline & & & $N(2)-C(18)$ & $1.452(11)$ & \\
\hline $\mathrm{F}(1)-\mathrm{Sb}(1)-\mathrm{N}(1)$ & $158.66(18)$ & $158.97(8)$ & $\mathrm{F}(1)-\mathrm{Sb}(1)-\mathrm{N}(1)$ & $161.74(16)$ & $161.48(9)$ \\
\hline $\mathrm{C}(1)-\mathrm{Sb}(1)-\mathrm{C}(20)$ & $93.4(3)$ & $102.15(11)$ & $\mathrm{C}(1)-\mathrm{Sb}(1)-\mathrm{C}(10)$ & $96.9(2)$ & $95.74(12)$ \\
\hline $\mathrm{F}(1)-\mathrm{Sb}(1)-\mathrm{C}(1)$ & $87.1(3)$ & $88.78(10)$ & $\mathrm{F}(1)-\mathrm{Sb}(1)-\mathrm{C}(1)$ & $89.69(19)$ & $88.94(11)$ \\
\hline $\mathrm{N}(1)-\mathrm{Sb}(1)-\mathrm{N}(2)$ & $120.87(19)$ & & $\mathrm{N}(1)-\mathrm{Sb}(1)-\mathrm{N}(2)$ & $86.25(14)$ & \\
\hline $\mathrm{N}(2)-\mathrm{Sb}(1)-\mathrm{C}(20)$ & $69.3(2)$ & & $\mathrm{N}(2)-\mathrm{Sb}(1)-\mathrm{C}(10)$ & $65.73(19)$ & \\
\hline $\mathrm{N}(2)-\mathrm{Sb}(1)-\mathrm{F}(1)$ & $78.06(19)$ & & $\mathrm{N}(2)-\mathrm{Sb}(1)-\mathrm{F}(1)$ & $108.11(15)$ & \\
\hline
\end{tabular}

Taking into account both intramolecular $\mathrm{N} \rightarrow \mathrm{Sb}$ interactions the coordination geometry around the antimony atom in 5 and 7 is distorted square pyramidal [ $\left[(\mathrm{C}, \mathrm{N})_{2} \mathrm{SbF}\right.$ core; hypervalent 12 -Sb-5 species $\left.{ }^{35,36}\right]$, with an ipso carbon atom in the apical position (Fig. 2 and S20†). For the fluorides 6 and 8, the molecules of which contain only one intramolecular $\mathrm{N} \rightarrow \mathrm{Sb}$ interaction, the coordination geometry is distorted pseudotrigonal bipyramidal [(C,N)CSbF core; hypervalent 10-Sb-4 species ${ }^{35,36}$, with the halogen and the nitrogen atoms placed in the axial positions. The intramolecular $\mathrm{N} \rightarrow \mathrm{Sb}$ interactions result in chelate induced-Sb-chirality ${ }^{34,37}$ and therefore the crystals of the fluorides 5 and 6 contain $1: 1$ mixtures of $\left(C_{\mathrm{Sb}}\right)$ and $\left(A_{\mathrm{Sb}}\right)$ isomers. ${ }^{28}$ While the resulting $\mathrm{SbC}_{3} \mathrm{~N}$ rings are basically planar for the imine ligands in 5 and 6 , the $\mathrm{C}_{3} \mathrm{SbN}$ rings in 7 and 8 are folded along the $\mathrm{Sb}^{\cdots} \mathrm{C}_{\text {methylene }}$ axis, with the $\mathrm{N}\left(\mathrm{sp}^{3}\right)$ atom lying out of the best plane through the residual $\mathrm{SbC}_{3}$ fragment. As result, in addition to the chirality at antimony, this folding induces planar chirality (with the aromatic ring and the nitrogen atom as chiral plane and pilot atom, respectively; for planar chirality the enantiomers are given as $p S_{\mathrm{N}}$ and $\left.p R_{\mathrm{N}}\right)$. $^{38}$ Indeed, the crystals contain racemic mixtures of $\left(C_{\mathrm{Sb}}\right)\left(p R_{\mathrm{N} 1}, p R_{\mathrm{N} 2}\right)-7 /\left(A_{\mathrm{Sb}}\right)\left(p S_{\mathrm{N} 1}, p S_{\mathrm{N} 2}\right)-7$ isomers and $\left(C_{\mathrm{Sb}}\right)\left(p S_{\mathrm{N} 1}\right)-8 /\left(A_{\mathrm{Sb}}\right)\left(p R_{\mathrm{N} 1}\right)-8$ isomers, respectively.

A closer investigation of the crystal packing revealed that, in addition to intramolecular $\mathrm{F} \cdots \mathrm{H}$ contacts established in the molecules of all fluorides $5-8$, intermolecular $\mathrm{F} \cdots \mathrm{H}$ and $\mathrm{C}-\mathrm{H} \cdots$ $\pi$ ( $\left.\mathrm{Ar}_{\text {centroid }}\right)$ interactions are present and led to different supramolecular architectures (see ESI†े). Thus, ribbon-like polymers of either $\left(C_{\mathrm{Sb}}\right)$ or $\left(A_{\mathrm{Sb}}\right)$ isomers based on $\mathrm{C}-\mathrm{H}_{\mathrm{aryl}} \cdots \pi$ $\left(A r_{\text {centroid }}\right)$ interactions are formed in the crystal of 5. Parallel pairs of chains built from $\left(C_{\mathrm{Sb}}\right)\left(p R_{\mathrm{N} 1}, p R_{\mathrm{N} 2}\right)-7$ or $\left(A_{\mathrm{Sb}}\right)\left(p S_{\mathrm{N} 1}, p S_{\mathrm{N} 2}\right)$ 7 isomers, respectively, through weak $\mathrm{F}(1) \cdots \mathrm{H}(3 \mathrm{a})_{\text {aryl }}$ contacts [2.49 ̊; $c f$. sum of the corresponding van der Waals radii, $\left.\sum r_{\mathrm{vdW}}(\mathrm{F}, \mathrm{H}) \quad 2.55 \AA^{27}\right]^{27}$ and $\mathrm{C}(14)-\mathrm{H}(14)_{\text {aryl }} \cdots \mathrm{Ar}_{\text {centroid }}\{\mathrm{C}(10 \mathrm{c})-$ $\mathrm{C}(15 \mathrm{c})\}\left(3.09 \AA ; \gamma=13.3^{\circ}\right)$ are developed along axis $b$ in the crystal of 7. By contrast, in the crystal of 6 a 3D architecture is formed based on weak $\mathrm{C}-\mathrm{H} \cdots \pi\left(\mathrm{Ar}_{\text {centroid }}\right)$ contacts between parallel chain polymers of alternating $\left(C_{\mathrm{Sb}}\right)-6$ and $\left(A_{\mathrm{sb}}\right)-6$ isomers connected through $\mathrm{F}(1) \cdots \mathrm{H}(7 \mathrm{~b})_{\text {imine }}(2.31 \AA)$ interactions. Surprisingly, no intermolecular $\mathrm{F} \cdots \mathrm{H}$ contacts are present in the crystal of 8; in this case a dimer association of $\left(C_{\mathrm{Sb}}\right)\left(p S_{\mathrm{N} 1}\right)$ 8 and $\left(A_{\mathrm{Sb}}\right)\left(p R_{\mathrm{N} 1}\right)-8$ isomers is formed through $\mathrm{C}(7)-$ $\mathrm{H}(7 \mathrm{~B})_{\text {methylene }} \cdots \mathrm{Ar}_{\text {centroid }}\left\{\mathrm{C}\left(10^{\prime}\right)-\mathrm{C}\left(15^{\prime}\right)\right\} \quad\left(2.99 \AA ; \gamma=17.7^{\circ}\right)$ contacts and these dimer units are further associated into a layer based on $\mathrm{C}(11)-\mathrm{H}(11)_{\text {ary }}{ }^{\cdots} \mathrm{Ar}_{\text {centroid }}\left\{\mathrm{C}\left(10^{\prime} \mathrm{a}\right)-\mathrm{C}\left(15^{\prime} \mathrm{a}\right)\right\}$ (3.02 $\AA ; \gamma=13.7^{\circ}$ ) contacts.

\section{Experimental}

\section{Materials and instrumentation}

The syntheses were performed under argon or nitrogen atmosphere using standard Schlenk techniques. THF was dried over sodium or potassium and distilled under argon prior to use. Reagents such as ${ }^{n} \mathrm{BuLi}, \mathrm{Tl}\left[\mathrm{PF}_{6}\right], \mathrm{Ag}\left[\mathrm{SbF}_{6}\right]$ and $\left[\mathrm{Bu}_{4} \mathrm{~N}\right] \mathrm{F}$ were purchased from commercial suppliers and used without further purification. The other starting materials were prepared according to the literature procedures: $2-\left(2^{\prime}, 6^{\prime}-{ }^{\mathrm{i}} \mathrm{Pr}_{2} \mathrm{C}_{6} \mathrm{H}_{3} \mathrm{~N}=\mathrm{CH}\right)$ $\mathrm{C}_{6} \mathrm{H}_{4} \mathrm{Br}, \quad\left[2-\left(2^{\prime}, 6^{\prime}-{ }^{\mathrm{i}} \mathrm{Pr}_{2} \mathrm{C}_{6} \mathrm{H}_{3} \mathrm{~N}=\mathrm{CH}\right) \mathrm{C}_{6} \mathrm{H}_{4}\right]_{2} \mathrm{SbBr}, \quad\left[2-\left(2^{\prime}, 4^{\prime}, 6^{\prime}-\right.\right.$ $\left.\left.\mathrm{Me}_{3} \mathrm{C}_{6} \mathrm{H}_{2} \mathrm{~N}=\mathrm{CH}\right) \mathrm{C}_{6} \mathrm{H}_{4}\right]_{2} \mathrm{SbBr},{ }^{18} \mathrm{PhSbCl}_{2},{ }^{15,39}\left[2-\left(\mathrm{Me}_{2} \mathrm{NCH}_{2}\right) \mathrm{C}_{6} \mathrm{H}_{4}\right]$ $\mathrm{PhSbCl}^{34}$ Elemental analyses were carried out with PerkinElmer 2400 and CHN-Analysator Type FlashAE 1112 (Co. Thermo) instruments. The melting point of compounds was measured with an Electrothermal 9200 or a Melting Point B-540 (Co. Büchi) apparatus. The ${ }^{1} \mathrm{H},{ }^{13} \mathrm{C},{ }^{19} \mathrm{~F}$ NMR spectra were recorded at room temperature using Bruker Avance 300 (for 2, 7, 8), Bruker Avance II 400 (for 5, 6) and Bruker Avance III 500 (for 
1, 3) instruments, respectively. The chemical shifts are reported in $\delta$ units relative to the residual peak of the solvent $\left(\mathrm{CHCl}_{3}\right.$, $\delta 7.26 \mathrm{ppm}$; DMSO- $d_{5}, \delta 2.50 \mathrm{ppm}$ ) in ${ }^{1} \mathrm{H}$ NMR spectra and to the peak of the deuterated solvent $\left(\mathrm{CDCl}_{3}, \delta 77.16 \mathrm{ppm}\right.$; DMSO- $d_{6}$, $\delta 39.52 \mathrm{ppm}$ ) in ${ }^{13} \mathrm{C}$ NMR spectra, respectively. ${ }^{40}$ The ${ }^{1} \mathrm{H}$ and ${ }^{13} \mathrm{C}$ resonances were assigned using 2D NMR experiments (COSY, HSQC and HMBC). The ${ }^{19} \mathrm{~F}$ and ${ }^{31} \mathrm{P}$ chemical shifts are quoted in $\delta$ units (ppm) relative to external standards $\left(\mathrm{CFCl}_{3}\right.$ for ${ }^{19} \mathrm{~F}$ NMR, and $\mathrm{H}_{3} \mathrm{PO}_{4} 85 \%$ for ${ }^{31} \mathrm{P}$ NMR, respectively). The NMR spectra were processed using the MestReNova software. ${ }^{41}$ Infrared spectra were recorded on a BioRad FTS-165 spectrometer, using ATR accessory. Mass spectra were recorded on a Thermo Scientific LTQ Orbitrap XL mass spectrometer equipped with a standard ESI/APCI source.

\section{Crystal structure determination}

Single crystals of $\mathbf{1} \cdot 2 \mathrm{CH}_{2} \mathrm{Cl}_{2}$ were obtained by slow diffusion of $n$-hexane into a solution of $\mathrm{CH}_{2} \mathrm{Cl}_{2}(3: 1 \mathrm{v} / \mathrm{v})$ or slow evaporation of a $\mathrm{CHCl}_{3}$ solution for $\mathbf{3} \cdot 2 \mathrm{CHCl}_{3}$. Colorless crystals of 5-8 were grown by slow evaporation of a $n$-hexane solution. The details of the crystal structure determination and refinement are given in Tables S1 and S2 (see ESI $\dagger$ ). The crystals were attached with Krytox $^{\mathrm{TM}}$ to a glass fiber $\left(\mathbf{1} \cdot 2 \mathrm{CH}_{2} \mathrm{Cl}_{2}, \mathbf{3} \cdot 2 \mathrm{CHCl}_{3}\right)$ or mounted on cryoloops (5-8). For $3 \cdot 2 \mathrm{CHCl}_{3}, 5-8$ data were collected at room temperature, while for $\mathbf{1} \cdot 2 \mathrm{CH}_{2} \mathrm{Cl}_{2}$ the crystal was cooled under a nitrogen stream at low temperature. Data were collected on Oxford (Type Gemini S) $\left(\mathbf{1} \cdot 2 \mathrm{CH}_{2} \mathrm{Cl}_{2}, \mathbf{3} \cdot 2 \mathrm{CHCl}_{3}\right)$ and Bruker SMART APEX (5-8) diffractometers, using graphitemonochromated Mo-K $\alpha$ radiation $(\lambda=0.71073 \AA)$, except for $3 \cdot 2 \mathrm{CHCl}_{3}$ for which $\mathrm{Cu}-\mathrm{K} \alpha(\lambda=0.54184 \AA)$ radiation was used. The structures were refined with anisotropic thermal parameters. The hydrogen atoms were refined with a riding model and a mutual isotropic thermal parameter. For structure solving and refinement the software package SHELX-97 was used. ${ }^{42}$ The drawings were created with the Diamond program. ${ }^{43}$ CCDC reference numbers $1020707\left(\mathbf{1} \cdot 2 \mathrm{CH}_{2} \mathrm{Cl}_{2}\right), 1020708\left(3 \cdot 2 \mathrm{CHCl}_{3}\right)$, 1020709 (5), 10207010 (6), 10207011 (7) and 10207012 (8) contain the supplementary crystallographic data for this paper. $\dagger$

Synthesis of $\left[\left\{2-\left(2^{\prime}, 6^{\prime}-{ }^{i} \mathrm{Pr}_{2} \mathrm{C}_{6} \mathrm{H}_{3} \mathrm{~N}=\mathrm{CH}\right) \mathrm{C}_{6} \mathrm{H}_{4}\right\}_{2} \mathrm{Sb}\right]^{+}\left[\mathrm{PF}_{6}\right]^{-}$(1). A suspension of $\mathrm{Tl}\left[\mathrm{PF}_{6}\right](0.750 \mathrm{~g}, 2.15 \mathrm{mmol})$ in $\mathrm{THF}(20 \mathrm{~mL})$ was added dropwise to a solution of $\left[2-\left(2^{\prime}, 6^{\prime}-{ }^{\mathrm{i}} \mathrm{Pr}_{2} \mathrm{C}_{6} \mathrm{H}_{3} \mathrm{~N}=\mathrm{CH}\right)\right.$ $\left.\mathrm{C}_{6} \mathrm{H}_{4}\right]_{2} \mathrm{SbBr}(1.570 \mathrm{~g}, 2.15 \mathrm{mmol})$ in $\mathrm{THF}(25 \mathrm{~mL})$ at room temperature, resulting in immediate formation of a white precipitate. The reaction mixture was stirred for $1.5 \mathrm{~h}$ and then filtered off through Celite. The solvent was removed in vacuum from the clear yellowish solution to give 1 as a pale yellow solid (1.380 g, 81\%), m.p. 235-237 ${ }^{\circ}$ C. Anal. calc. for $\mathrm{C}_{38} \mathrm{H}_{44} \mathrm{~F}_{6} \mathrm{~N}_{2} \mathrm{PSb}$ (795.49): C, 57.37; H, 5.58; N, 3.52. Found: C, 57.31; H, 5.46; N, $3.30 \%$. IR (ATR, $\left.\mathrm{cm}^{-1}\right): 1606(\mathrm{~m})[\nu(\mathrm{CH}=\mathrm{N})], 834(\mathrm{~s})[\nu(\mathrm{P}-\mathrm{F})] .{ }^{1} \mathrm{H}$ NMR (500 MHz, $\mathrm{CDCl}_{3}$ ): $\delta 1.17\left[\mathrm{~d},{ }^{3} J_{\mathrm{H}, \mathrm{H}}=6.7 \mathrm{~Hz}, 6 \mathrm{H}, \mathrm{H}-8^{\prime} \mathrm{a} 1\right.$, $\left.\mathrm{CH}\left(\mathrm{CH}_{3}\right)_{2}\right], 1.38\left[\mathrm{~d},{ }^{3} \mathrm{~J}_{\mathrm{H}, \mathrm{H}}=6.8 \mathrm{~Hz}, 6 \mathrm{H}, \mathrm{H}-8^{\prime} \mathrm{a} 2, \mathrm{CH}\left(\mathrm{CH}_{3}\right)_{2}\right], 1.43$ $\left[\mathrm{d},{ }^{3} J_{\mathrm{H}, \mathrm{H}}=6.7 \mathrm{~Hz}, 6 \mathrm{H}, \mathrm{H}-8^{\prime} \mathrm{b} 1, \mathrm{CH}\left(\mathrm{CH}_{3}\right)_{2}\right], 1.51\left[\mathrm{~d},{ }^{3} J_{\mathrm{H}, \mathrm{H}}=6.6 \mathrm{~Hz}\right.$, $6 \mathrm{H}, \mathrm{H}-8^{\prime} \mathrm{b} 2, \mathrm{CH}\left(\mathrm{CH}_{3}\right)_{2}$ ] $3.03\left[\mathrm{sept},{ }^{3} \mathrm{~J}_{\mathrm{H}, \mathrm{H}}=6.7 \mathrm{~Hz}, 2 \mathrm{H}, \mathrm{H}-7^{\prime} \mathrm{b}\right.$, $\left.\mathrm{CH}\left(\mathrm{CH}_{3}\right)_{2}\right], 3.29\left[\mathrm{sept},{ }^{3} J_{\mathrm{H}, \mathrm{H}}=6.7 \mathrm{~Hz}, 2 \mathrm{H}, \mathrm{H}-7^{\prime} \mathrm{a}, \mathrm{CH}\left(\mathrm{CH}_{3}\right)_{2}\right], 7.34$ (dd, ${ }^{3} J_{\mathrm{H}, \mathrm{H}}=6.3 \mathrm{~Hz},{ }^{4} J_{\mathrm{H}, \mathrm{H}}=2.8 \mathrm{~Hz}, 2 \mathrm{H}, \mathrm{H}-3^{\prime} \mathrm{a}$ or $\mathrm{H}-3^{\prime} \mathrm{b}, \mathrm{C}_{6} H_{3}$ ), $7.46\left(\mathrm{~m}, 4 \mathrm{H}, \mathrm{H}-3^{\prime} \mathrm{b}\right.$ or H-3'a, H- $\left.4^{\prime}, \mathrm{C}_{6} H_{3}\right), 7.52\left(\mathrm{~d},{ }^{3} \mathrm{~J}_{\mathrm{H}, \mathrm{H}}=7.4 \mathrm{~Hz}\right.$, $2 \mathrm{H}, \mathrm{H}-6, \mathrm{C}_{6} H_{4}$ ), 7.59 (ddd, ${ }^{3} J_{\mathrm{H}, \mathrm{H}}=7.5 \mathrm{~Hz},{ }^{4} J_{\mathrm{H}, \mathrm{H}}=1.2 \mathrm{~Hz}, 2 \mathrm{H}, \mathrm{H}-$ $\left.5, \mathrm{C}_{6} H_{4}\right), 7.70\left(\mathrm{ddd},{ }^{3} J_{\mathrm{H}, \mathrm{H}}=7.5 \mathrm{~Hz},{ }^{4} J_{\mathrm{H}, \mathrm{H}}=1.1 \mathrm{~Hz}, 2 \mathrm{H}, \mathrm{H}-4\right.$, $\left.\mathrm{C}_{6} H_{4}\right), 8.17\left(\mathrm{dd},{ }^{3} J_{\mathrm{H}, \mathrm{H}}=7.6 \mathrm{~Hz},{ }^{4} J_{\mathrm{H}, \mathrm{H}}=0.9 \mathrm{~Hz}, 2 \mathrm{H}, \mathrm{H}-3, \mathrm{C}_{6} H_{4}\right)$, $8.94(\mathrm{~s}, 2 \mathrm{H}, \mathrm{H}-7, \mathrm{CH}=\mathrm{N}) .{ }^{13} \mathrm{C}\left\{{ }^{1} \mathrm{H}\right\} \mathrm{NMR}\left(75.5 \mathrm{MHz}, \mathrm{CDCl}_{3}\right)$ : $\delta 23.86\left[\mathrm{~s}, \mathrm{C}-8^{\prime} \mathrm{b} 2, \mathrm{CH}\left(\mathrm{CH}_{3}\right)_{2}\right], 24.49$ [s, C-8' $\left.{ }^{\prime} \mathrm{a} 2, \mathrm{CH}\left(\mathrm{CH}_{3}\right)_{2}\right], 24.78$ [s, C-8' a1, $\left.\mathrm{CH}\left(\mathrm{CH}_{3}\right)_{2}\right], 27.35\left[\mathrm{~s}, \mathrm{C}-8^{\prime} \mathrm{b} 1, \mathrm{CH}\left(\mathrm{CH}_{3}\right)_{2}\right], 28.96\left[\mathrm{~s}, \mathrm{C}-7^{\prime} \mathrm{b}\right.$, $\mathrm{CH}\left(\mathrm{CH}_{3}\right)_{2}$ ], 30.21 [s, C-7'a, $\mathrm{CH}\left(\mathrm{CH}_{3}\right)_{2}$ ], 125.14, 126.21, 129.23 (s, C-3'a, C-3'b, C-4'), 131.61 (s, C-4), 135.01 (s, C-6), 135.14 (s, C-5), 135.82 (s, C-3), 138.78 (s, C-2), 140.27 (s, C-2'b), 141.12 (s, C-1'), 141.36 (s, C-2'a), 146.94 (s, C-1), 174.41 (s, C-7, CH=N). ${ }^{19} \mathrm{~F}\left\{{ }^{1} \mathrm{H}\right\}$ NMR (282.4 MHz, $\left.\mathrm{CDCl}_{3}\right): \delta-73.0\left(\mathrm{~d},{ }^{1} J_{\mathrm{P}, \mathrm{F}}=713.1 \mathrm{~Hz}\right) .{ }^{31} \mathrm{P}\left\{{ }^{1} \mathrm{H}\right\}$ NMR (121.5 MHz, $\mathrm{CDCl}_{3}$ ): $\delta-144.3$ (sept, ${ }^{1} J_{\mathrm{P}, \mathrm{F}}=713.3 \mathrm{~Hz}$ ). MS (ESI+, $\left.\mathrm{CH}_{2} \mathrm{Cl}_{2} / \mathrm{CH}_{3} \mathrm{CN}\right): m / z$ (\%) 649 (100) $\left[\mathrm{R}_{2} \mathrm{Sb}^{+}\right][\mathrm{R}=2$ $\left.\left(2^{\prime}, 6^{\prime}-{ }^{\mathrm{i}} \mathrm{Pr}_{2} \mathrm{C}_{6} \mathrm{H}_{3} \mathrm{~N}=\mathrm{CH}\right) \mathrm{C}_{6} \mathrm{H}_{4}\right]$.

Synthesis of $\left[\left\{2-\left(2^{\prime}, 6^{\prime}{ }^{\mathrm{i}}{ }^{-} \mathrm{Pr}_{2} \mathrm{C}_{6} \mathrm{H}_{3} \mathbf{N}=\mathbf{C H}\right) \mathrm{C}_{6} \mathbf{H}_{4}\right\} \mathbf{P h S b}\right]^{+}\left[\mathrm{PF}_{6}\right]^{-}$(2). A solution of ${ }^{n} \mathrm{BuLi}$ in $n$-hexane $(5.45 \mathrm{~mL}, 8.7 \mathrm{mmol}, 1.6 \mathrm{M})$ was added dropwise, at $-78{ }^{\circ} \mathrm{C}$ to a stirred solution of $2-\left(2^{\prime}, 6^{\prime}{ }^{\mathrm{i}} \mathrm{Pr}_{2}-\right.$ $\left.\mathrm{C}_{6} \mathrm{H}_{3} \mathrm{~N}=\mathrm{CH}\right) \mathrm{C}_{6} \mathrm{H}_{4} \mathrm{Br}(3.00 \mathrm{~g}, 8.7 \mathrm{mmol})$ in anhydrous $n$-hexane $(40 \mathrm{~mL})$ and the reaction mixture was stirred for $1.5 \mathrm{~h}$. The resulting yellow-orange suspension of organolithium compound was added dropwise to a suspension of $\mathrm{PhSbCl}_{2}$ $(2.35,8.7 \mathrm{mmol})$ in $n$-hexane $(30 \mathrm{~mL})$, at $-78{ }^{\circ} \mathrm{C}$, and the mixture was stirred for $2 \mathrm{~h}$ at $-78{ }^{\circ} \mathrm{C}$, then for $12 \mathrm{~h}$ at room temperature. The solvent was removed, the residual yellow-orange solid was washed several times with cold $n$-hexane and then extracted with $\mathrm{CH}_{2} \mathrm{Cl}_{2}$. Evaporation of the solvent in vacuum gave $2.15 \mathrm{~g}$ $(50 \%)$ of $\left[2-\left(2^{\prime}, 6^{\prime}-{ }^{\mathrm{i}} \mathrm{Pr}_{2} \mathrm{C}_{6} \mathrm{H}_{3} \mathrm{~N}=\mathrm{CH}\right) \mathrm{C}_{6} \mathrm{H}_{4}\right] \mathrm{PhSbCl}$ as a yellow powder (m.p. 233-235 ${ }^{\circ} \mathrm{C}$; $c f .238{ }^{\circ} \mathrm{C}$ (ref. 32)) which was used without further purification. To a solution of this chloride $(1.00$ $\mathrm{g}, 2.00 \mathrm{mmol})$ in THF $(25 \mathrm{~mL})$ a suspension of $\mathrm{Tl}\left[\mathrm{PF}_{6}\right](0.70 \mathrm{~g}$, $2.00 \mathrm{mmol})$ in THF $(15 \mathrm{~mL})$ was added dropwise, at room temperature. A white precipitate is formed immediately. The reaction mixture was stirred for $2 \mathrm{~h}$ and then filtered off through Celite. The solvent was removed under vacuum from the paleyellow solution and the resulting precipitate was washed with $n$-hexane to give 2 as a pale yellow solid (0.873 g, 72\%), m.p. 169-170 ${ }^{\circ} \mathrm{C}$. Anal. calc. for $\mathrm{C}_{25} \mathrm{H}_{27} \mathrm{~F}_{6} \mathrm{NPSb}$ (608.21): C, 49.37; $\mathrm{H}$, 4.47; N, 2.30. Found: C, 49.02; H, 4.26; N, 2.33\%. IR (ATR, $\mathrm{cm}^{-1}$ ): $1615(\mathrm{~m})[\nu(\mathrm{CH}=\mathrm{N})], 802(\mathrm{~s})[\nu(\mathrm{P}-\mathrm{F})] .{ }^{1} \mathrm{H}$ NMR $\left(300 \mathrm{MHz}, \mathrm{CDCl}_{3}\right)$ : $\delta 0.35\left[\mathrm{~d},{ }^{3} J_{\mathrm{H}, \mathrm{H}}=6.7 \mathrm{~Hz}, 3 \mathrm{H}, \mathrm{H}-8^{\prime} \mathrm{a} 1, \mathrm{CH}\left(\mathrm{CH}_{3}\right)_{2}\right], 0.88\left[\mathrm{~d},{ }^{3} \mathrm{~J}_{\mathrm{H}, \mathrm{H}}=\right.$ $\left.6.8 \mathrm{~Hz}, 3 \mathrm{H}, \mathrm{H}-8^{\prime} \mathrm{a} 2, \mathrm{CH}\left(\mathrm{CH}_{3}\right)_{2}\right], 1.13\left[\mathrm{~d},{ }^{3} J_{\mathrm{H}, \mathrm{H}}=6.8 \mathrm{~Hz}, 3 \mathrm{H}, \mathrm{H}-\right.$ $\left.8^{\prime} \mathrm{b} 1, \mathrm{CH}\left(\mathrm{CH}_{3}\right)_{2}\right], 1.34\left[\mathrm{~d},{ }^{3} J_{\mathrm{H}, \mathrm{H}}=6.8 \mathrm{~Hz}, 3 \mathrm{H}, \mathrm{H}-8^{\prime} \mathrm{b} 2, \mathrm{CH}\left(\mathrm{CH}_{3}\right)_{2}\right]$, $1.73\left[\mathrm{sept},{ }^{3} \mathrm{~J}_{\mathrm{H}, \mathrm{H}}=6.8 \mathrm{~Hz}, 1 \mathrm{H}, \mathrm{H}-7^{\prime} \mathrm{a}, \mathrm{CH}\left(\mathrm{CH}_{3}\right)_{2}\right.$ ], $2.93\left[\mathrm{sept},{ }^{3} J_{\mathrm{H}, \mathrm{H}}\right.$

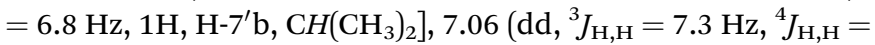
$\left.1.3 \mathrm{~Hz}, 1 \mathrm{H}, \mathrm{H}-3^{\prime} \mathrm{a}, \mathrm{C}_{6} \mathrm{H}_{3}\right), 7.26\left(\mathrm{~m}, 7 \mathrm{H}, \mathrm{H}-3^{\prime} \mathrm{b}, \mathrm{H}-4^{\prime}, \mathrm{C}_{6} \mathrm{H}_{3}+\mathrm{H}-\right.$ ortho,meta,para, $\left.\mathrm{C}_{6} H_{5}\right), 7.77\left(\mathrm{dd},{ }^{3} J_{\mathrm{H}, \mathrm{H}}=7.3 \mathrm{~Hz}, 1 \mathrm{H}, \mathrm{H}-4, \mathrm{C}_{6} H_{4}\right)$, $7.84\left(\mathrm{ddd},{ }^{3} J_{\mathrm{H}, \mathrm{H}}=7.5 \mathrm{~Hz},{ }^{4} J_{\mathrm{H}, \mathrm{H}}=1.0 \mathrm{~Hz}, 1 \mathrm{H}, \mathrm{H}-5, \mathrm{C}_{6} H_{4}\right), 8.08(\mathrm{~d}$, $\left.{ }^{3} J_{\mathrm{H}, \mathrm{H}}=7.1 \mathrm{~Hz}, 1 \mathrm{H}, \mathrm{H}-3, \mathrm{C}_{6} H_{4}\right), 8.38\left(\mathrm{~s}, \mathrm{br}, 1 \mathrm{H}, \mathrm{H}-6, \mathrm{C}_{6} H_{4}\right), 8.65$ (s, $1 \mathrm{H}, \mathrm{H}-7, \mathrm{CH}=\mathrm{N}) .{ }^{13} \mathrm{C}\left\{{ }^{1} \mathrm{H}\right\} \mathrm{NMR}\left(75.5 \mathrm{MHz}, \mathrm{CDCl}_{3}\right): \delta 22.33[\mathrm{~s}, \mathrm{C}-$ $\left.8^{\prime} \mathrm{a} 1, \mathrm{CH}\left(\mathrm{CH}_{3}\right)_{2}\right], 23.98$ [s, C-8'b2, $\left.\mathrm{CH}\left(\mathrm{CH}_{3}\right)_{2}\right], 24.98$ [s, C-8'b1, $\left.\mathrm{CH}\left(\mathrm{CH}_{3}\right)_{2}\right], 26.07 \quad\left[\mathrm{~s}, \mathrm{C}-8^{\prime} \mathrm{a} 2, \mathrm{CH}\left(\mathrm{CH}_{3}\right)_{2}\right], 28.13 \quad\left[\mathrm{~s}, \mathrm{C}-7^{\prime} \mathrm{a}\right.$, $\mathrm{CH}\left(\mathrm{CH}_{3}\right)_{2}$ ], 29.15 [s, C-7'b, $\mathrm{CH}\left(\mathrm{CH}_{3}\right)_{2}$ ] 123.98 (s, C-3'b), 124.26 (s, C-3'a), 127.94 (s, C-4'), 129.39 (s, C-meta), 130.15 (s, C-4), 130.44 (s, C-para), 133.60 (s, C-3), 134.41 (s, C-ortho), 134.58 (s, C-5), 136.13 (s, C-6), 139.64 (s, C-1'), 140.39 (s, C-2), 140.66 (s, C-2'b), 141.02 (s, C-2'a), 144.45 (s, C-ipso), 151.42 (s, C-1), 174.86 
$(\mathrm{s}, \mathrm{C}-7, \mathrm{CH}=\mathrm{N}) \cdot{ }^{19} \mathrm{~F}\left\{{ }^{1} \mathrm{H}\right\} \mathrm{NMR}\left(282.4 \mathrm{MHz}, \mathrm{CDCl}_{3}\right): \delta-72.9(\mathrm{~d}$, $\left.{ }^{1} J_{\mathrm{P}, \mathrm{F}}=713.1 \mathrm{~Hz}\right) .{ }^{31} \mathrm{P}\left\{{ }^{1} \mathrm{H}\right\} \mathrm{NMR}\left(121.5 \mathrm{MHz}, \mathrm{CDCl}_{3}\right): \delta-144.3$ (sept, ${ }^{1} J_{\mathrm{P}, \mathrm{F}}=713.3 \mathrm{~Hz}$ ). MS (APCI+, $\left.\mathrm{CH}_{3} \mathrm{CN}\right): m / z$ (\%) 462 (100) $\left[\mathrm{RPhSb}^{+}\right]\left[\mathrm{R}=2-\left(2^{\prime}, 6^{\prime}-{ }^{\mathrm{i}} \mathrm{Pr}_{2} \mathrm{C}_{6} \mathrm{H}_{3} \mathrm{~N}=\mathrm{CH}\right) \mathrm{C}_{6} \mathrm{H}_{4}\right]$.

Synthesis of $\left[\left\{2-\left(2^{\prime}, 4^{\prime}, 6^{\prime}-\mathrm{Me}_{3} \mathrm{C}_{6} \mathrm{H}_{2} \mathrm{~N}=\mathrm{CH}\right) \mathrm{C}_{6} \mathrm{H}_{4}\right\}_{2} \mathrm{Sb}\right]^{+}\left[\mathrm{PF}_{6}\right]^{-}$ (3). A suspension of $\mathrm{Tl}\left[\mathrm{PF}_{6}\right](0.120 \mathrm{~g}, 0.34 \mathrm{mmol})$ in THF $(15 \mathrm{~mL})$ was added dropwise to a solution of $\left[2-\left(2^{\prime}, 4^{\prime}, 6^{\prime}-\mathrm{Me}_{3} \mathrm{C}_{6} \mathrm{H}_{2} \mathrm{~N}=\mathrm{CH}\right)\right.$ $\left.\mathrm{C}_{6} \mathrm{H}_{4}\right]_{2} \mathrm{SbBr}(0.222 \mathrm{~g}, 0.34 \mathrm{mmol})$ in THF $(20 \mathrm{~mL})$ at room temperature, resulting in immediate formation of a white precipitate. The reaction mixture was stirred for $1.5 \mathrm{~h}$ and then filtered off through Celite. The solvent was removed in vacuum from the clear yellowish solution to give 3 as a pale yellow solid (0.139 g, 57\%), m.p. 200-202 ${ }^{\circ} \mathrm{C}$. Anal. calc. for $\mathrm{C}_{32} \mathrm{H}_{32} \mathrm{~F}_{6} \mathrm{~N}_{2} \mathrm{PSb}$ (711.33): C, 54.03; H, 4.53; N, 3.94. Found: C, 53.16; H, 4.61; N, $3.89 \%$. IR (ATR, $\left.\mathrm{cm}^{-1}\right): 1602(\mathrm{~m})[\nu(\mathrm{CH}=\mathrm{N})], 825(\mathrm{~s})[\nu(\mathrm{P}-\mathrm{F})] .{ }^{1} \mathrm{H}$ $\mathrm{NMR}\left(500 \mathrm{MHz}, \mathrm{CDCl}_{3}\right): \delta 2.37\left(\mathrm{~s}, 6 \mathrm{H}, \mathrm{H}-8^{\prime}, \mathrm{CH}_{3}\right), 2.45(\mathrm{~s}, 12 \mathrm{H}, \mathrm{H}-$ $\left.7^{\prime}, \mathrm{CH}_{3}\right), 7.11\left(\mathrm{~s}, 4 \mathrm{H}, \mathrm{H}-3^{\prime}, 5^{\prime}, \mathrm{C}_{6} H_{2}\right), 7.48\left(\mathrm{~d},{ }^{3} J_{\mathrm{H}, \mathrm{H}}=7.5 \mathrm{~Hz}, 2 \mathrm{H}, \mathrm{H}-\right.$ 6, $\left.\mathrm{C}_{6} H_{4}\right), 7.55\left(\mathrm{ddd},{ }^{3} J_{\mathrm{H}, \mathrm{H}}=7.5 \mathrm{~Hz},{ }^{4} J_{\mathrm{H}, \mathrm{H}}=1.2 \mathrm{~Hz}, 2 \mathrm{H}, \mathrm{H}-5\right.$, $\left.\mathrm{C}_{6} H_{4}\right), 7.62\left(\mathrm{ddd},{ }^{3} J_{\mathrm{H}, \mathrm{H}}=7.5 \mathrm{~Hz},{ }^{4} \mathrm{~J}_{\mathrm{H}, \mathrm{H}}=1.1 \mathrm{~Hz}, 2 \mathrm{H}, \mathrm{H}-4\right.$, $\left.\mathrm{C}_{6} \mathrm{H}_{4}\right), 8.12\left(\mathrm{dd},{ }^{3} J_{\mathrm{H}, \mathrm{H}}=7.5 \mathrm{~Hz},{ }^{4} \mathrm{~J}_{\mathrm{H}, \mathrm{H}}=0.8 \mathrm{~Hz}, 2 \mathrm{H}, \mathrm{H}-3, \mathrm{C}_{6} H_{4}\right)$, $8.94(\mathrm{~s}, 2 \mathrm{H}, \mathrm{H}-7, \mathrm{CH}=\mathrm{N}) \cdot{ }^{13} \mathrm{C}\left\{{ }^{1} \mathrm{H}\right\} \mathrm{NMR}\left(125.8 \mathrm{MHz}, \mathrm{CDCl}_{3}\right)$ : $\delta 20.25$ (s, br, C-7' $\left.C^{\prime} \mathrm{H}_{3}\right), 21.07\left(\mathrm{~s}, \mathrm{C}-8^{\prime}, \mathrm{CH}_{3}\right), 129.79\left(\mathrm{~s}, \mathrm{C}-2^{\prime}, 6^{\prime}\right)$, 131.26 (s, C-4), 131.36 (s, C-3' ${ }^{\prime} 5^{\prime}$ ), 134.96 (s, C-5), 135.12 (s, C-6), 135.29 (s, C-3), 138.58 (s, C-4'), 138.72 (s, C-2), 142.30 (s, C-1'), 146.17 (s, C-1), $174.43(\mathrm{~s}, \mathrm{C}-7, C \mathrm{H}=\mathrm{N}) .{ }^{19} \mathrm{~F}\left\{{ }^{1} \mathrm{H}\right\} \mathrm{NMR}(282.4$ $\mathrm{MHz}_{\mathrm{CDCl}}$ ): $\delta-72.8\left(\mathrm{~d},{ }^{1} J_{\mathrm{P}, \mathrm{F}}=713.2 \mathrm{~Hz}\right) .{ }^{31} \mathrm{P}\left\{{ }^{1} \mathrm{H}\right\} \mathrm{NMR}(202.5$ $\mathrm{MHz} \mathrm{CDCl}_{3}$ ): $\delta-144.3$ (sept, ${ }^{1} J_{\mathrm{P}, \mathrm{F}}=713.2 \mathrm{~Hz}$ ). MS (ESI+, $\left.\mathrm{CH}_{2} \mathrm{Cl}_{2} / \mathrm{CH}_{3} \mathrm{CN}\right): m / z(\%) 565$ (100) $\left[\mathrm{R}_{2}^{\prime} \mathrm{Sb}^{+}\right]\left[\mathrm{R}^{\prime}=2-\left(2^{\prime}, 4^{\prime}, 6^{\prime}-\right.\right.$ $\left.\left.\mathrm{Me}_{3} \mathrm{C}_{6} \mathrm{H}_{2} \mathrm{~N}=\mathrm{CH}\right) \mathrm{C}_{6} \mathrm{H}_{4}\right]$.

Synthesis of $\left[\left\{2-\left(\mathrm{Me}_{2} \mathrm{NCH}_{2}\right) \mathrm{C}_{6} \mathrm{H}_{4}\right\}_{2} \mathrm{Sb}\right]^{+}\left[\mathrm{SbF}_{6}\right]^{-}$(4). To a solution of $\left[2-\left(\mathrm{Me}_{2} \mathrm{NCH}_{2}\right) \mathrm{C}_{6} \mathrm{H}_{4}\right]_{2} \mathrm{SbCl}(0.48 \mathrm{~g}, 1.13 \mathrm{mmol})$ in THF (15 $\mathrm{mL})$ was added a suspension of $\mathrm{Ag}\left[\mathrm{SbF}_{6}\right](0.39 \mathrm{~g}, 1.13 \mathrm{mmol})$ in THF (10 mL), which lead to the immediate formation of a white precipitate. The flask was covered with aluminum foil against light. The reaction mixture was stirred for 30 minutes and then filtered off through Celite, resulting in a colorless solution. Removal of the solvent under vacuum gave 4 as a white solid (0.35 g, 50\%), m.p. $212-214^{\circ}$ C. Anal. calc. for $\mathrm{C}_{18} \mathrm{H}_{24} \mathrm{~F}_{6} \mathrm{~N}_{2} \mathrm{Sb}_{2}$ (625.91): C, 34.54; H, 3.86; N, 4.48. Found: C, 34.58; H, 4.09; N, $4.47 \%$. IR (ATR, $\left.\mathrm{cm}^{-1}\right): 750(\mathrm{~s})[\nu(\mathrm{Sb}-\mathrm{F})] .{ }^{1} \mathrm{H}$ NMR $(300 \mathrm{MHz}$, DMSO- $\left.d_{6}\right): \delta 2.42\left(\mathrm{~s}, 12 \mathrm{H}, \mathrm{CH}_{3}\right), 3.90\left(\mathrm{~s}, 4 \mathrm{H}, \mathrm{CH}_{2}\right), 7.44\left(\mathrm{~m}, 6 \mathrm{H}, \mathrm{H}^{-}\right.$ $\left.3,4,5, \mathrm{C}_{6} H_{4}\right), 7.61\left(\mathrm{~d},{ }^{3} J_{\mathrm{H}, \mathrm{H}}=6.0 \mathrm{~Hz}, 2 \mathrm{H}, \mathrm{H}-6, \mathrm{C}_{6} H_{4}\right) .{ }^{13} \mathrm{C}\left\{{ }^{1} \mathrm{H}\right\}$ NMR (75.5 MHz, DMSO- $\left.d_{6}\right): \delta 45.44\left(\mathrm{~s}, C_{3}\right), 65.36\left(\mathrm{~s}, \mathrm{CH}_{2}\right)$, 128.48 (s, C-5 or C-3), 128.56 (s, C-3 or C-5), 129.96 (s, C-4), 135.08 (s, C-6), 143.96 (s, C-2), 145.58 (s, C-1). ${ }^{19} \mathrm{~F}\left\{{ }^{1} \mathrm{H}\right\}$ NMR (282.4 MHz, DMSO- $\left.d_{6}\right): \delta-119.5(\mathrm{~m}) . \mathrm{MS}\left(\mathrm{ESI}+, \mathrm{CH}_{3} \mathrm{CN}\right): m / z$ (\%) 389 (100) $\left[\mathrm{R}_{2}^{\prime \prime} \mathrm{Sb}^{+}\right]\left[\mathrm{R}^{\prime \prime}=2-\left(\mathrm{Me}_{2} \mathrm{NCH}_{2}\right) \mathrm{C}_{6} \mathrm{H}_{4}\right]$.

Synthesis of $\left[2-\left(2^{\prime}, 6^{\prime}-{ }^{i}{ }^{-} r_{2} \mathrm{C}_{6} \mathrm{H}_{3} \mathrm{~N}=\mathrm{CH}\right) \mathrm{C}_{6} \mathrm{H}_{4}\right]_{2} \mathrm{SbF}$ (5). A solution of $\left[\mathrm{Bu}_{4} \mathrm{~N}\right] \mathrm{F} \cdot 3 \mathrm{H}_{2} \mathrm{O}(0.088 \mathrm{~g}, 0.28 \mathrm{mmol})$ in acetonitrile (10 $\mathrm{mL})$ was added to a solution of $1(0.224 \mathrm{~g}, 0.28 \mathrm{mmol})$ in acetonitrile $(15 \mathrm{~mL})$. The reaction mixture was stirred for $16 \mathrm{~h}$, the color of the solution being changed from colourless to yellow. The solvent was removed in vacuum to obtain a yellow precipitate, which was extracted with $n$-hexane. Slow evaporation of the clear $n$-hexane solution gave yellow crystals of 5 (0.103 g, 55\%), m.p. $166-168{ }^{\circ} \mathrm{C}$. Anal. calc. for $\mathrm{C}_{38} \mathrm{H}_{44} \mathrm{FN}_{2} \mathrm{Sb}$ (669.53): C, 68.17; H, 6.62; N, 4.18. Found: C, 68.46; H, 6.81; N,
4.34\%. IR (ATR, $\left.\mathrm{cm}^{-1}\right): 1641(\mathrm{~m})[\nu(\mathrm{CH}=\mathrm{N})] .{ }^{1} \mathrm{H}$ NMR $(300 \mathrm{MHz}$, $\left.\mathrm{CDCl}_{3}\right): \delta 0.44\left[\mathrm{~d},{ }^{3} J_{\mathrm{H}, \mathrm{H}}=5.4 \mathrm{~Hz}, 3 \mathrm{H}, \mathrm{H}-8^{\prime} \mathrm{a} 1(\mathrm{~A}), \mathrm{CH}\left(\mathrm{CH}_{3}\right)_{2}\right], 0.73$ $\left[\mathrm{d},{ }^{3} J_{\mathrm{H}, \mathrm{H}}=5.3 \mathrm{~Hz}, 3 \mathrm{H}, \mathrm{H}-8^{\prime} \mathrm{a} 2(\mathrm{~A}), \mathrm{CH}\left(\mathrm{CH}_{3}\right)_{2}\right], 0.88\left[\mathrm{~d},{ }^{3} J_{\mathrm{H}, \mathrm{H}}=5.3\right.$ $\mathrm{Hz}, 6 \mathrm{H}, \mathrm{H}-8^{\prime} 1$ (B), $\left.\mathrm{CH}\left(\mathrm{CH}_{3}\right)_{2}\right], 1.06\left[\mathrm{~m}, 12 \mathrm{H}, \mathrm{H}-8^{\prime} \mathrm{b} 1\right.$ (A) $+\mathrm{H}-8^{\prime} \mathrm{b} 2$ (A) $+\mathrm{H}-8^{\prime} 2$ (B) $\left.\mathrm{CH}\left(\mathrm{CH}_{3}\right)_{2}\right], 1.91\left[\mathrm{~m}, 1 \mathrm{H}, \mathrm{H}-7^{\prime} \mathrm{a}(\mathrm{A}), \mathrm{CH}\left(\mathrm{CH}_{3}\right)_{2}\right], 2.80$ $\left[\mathrm{m}, 3 \mathrm{H}, \mathrm{H}-7^{\prime} \mathrm{b}(\mathrm{A})+\mathrm{H}-7^{\prime}(\mathrm{B}), \mathrm{CH}\left(\mathrm{CH}_{3}\right)_{2}\right], 6.98\left[\mathrm{~s}, \mathrm{br}, 1 \mathrm{H}, \mathrm{H}-3^{\prime} \mathrm{a}(\mathrm{A})\right.$, $\left.\mathrm{C}_{6} H_{3}\right], 7.11\left[\mathrm{~s}, \mathrm{br}, 5 \mathrm{H}, \mathrm{H}-3^{\prime} \mathrm{b}(\mathrm{A})+\mathrm{H}-4^{\prime}(\mathrm{A})+\mathrm{H}-3^{\prime}(\mathrm{B})+\mathrm{H}-4^{\prime}(\mathrm{B})\right.$, $\left.\mathrm{C}_{6} H_{3}\right], 7.22\left[\mathrm{~s}, \mathrm{br}, 1 \mathrm{H}, \mathrm{H}-6(\mathrm{~B}), \mathrm{C}_{6} \mathrm{H}_{4}\right], 7.26$ [s, br, $1 \mathrm{H}, \mathrm{H}-5$ (B), $\left.\mathrm{C}_{6} H_{4}\right], 7.44\left[\mathrm{dd}, 1 \mathrm{H},{ }^{3} J_{\mathrm{H}, \mathrm{H}}=6.4 \mathrm{~Hz}, \mathrm{H}-4(\mathrm{~B}), \mathrm{C}_{6} H_{4}\right], 7.62[\mathrm{~m}, 2 \mathrm{H}$, $\mathrm{H}-4(\mathrm{~A})+\mathrm{H}-3$ (B), $\left.\mathrm{C}_{6} H_{4}\right], 7.74\left[\mathrm{dd},{ }^{3} J_{\mathrm{H}, \mathrm{H}}=7.3 \mathrm{~Hz}, 1 \mathrm{H}, \mathrm{H}-5\right.$ (A), $\left.\mathrm{C}_{6} H_{4}\right], 7.85\left[\mathrm{~d},{ }^{3} J_{\mathrm{H}, \mathrm{H}}=6.7 \mathrm{~Hz}, 1 \mathrm{H}, \mathrm{H}-3(\mathrm{~A}), \mathrm{C}_{6} H_{4}\right], 8.38[\mathrm{~m}, 3 \mathrm{H}, \mathrm{H}-$ 6 (A), $\mathrm{C}_{6} \mathrm{H}_{4}+\mathrm{H}-7$ (A) + H-7 (B), $\left.\mathrm{CH}=\mathrm{N}\right] .{ }^{13} \mathrm{C}\left\{{ }^{1} \mathrm{H}\right\} \mathrm{NMR}(75.5 \mathrm{MHz}$, $\left.\mathrm{CDCl}_{3}\right): \delta 22.12\left[\mathrm{~s}, \mathrm{C}-8^{\prime} \mathrm{a} 1\right.$ (A), $\left.\mathrm{CH}\left(\mathrm{CH}_{3}\right)_{2}\right], 23.78$ [s, C-8'1 (B), $\mathrm{CH}\left(\mathrm{CH}_{3}\right)_{2}$ ], 24.03 [s, C-8'2 (B), $\left.\mathrm{CH}\left(\mathrm{CH}_{3}\right)_{2}\right], 24.40$ [s, C-8'b1 (A), $\left.\mathrm{CH}\left(\mathrm{CH}_{3}\right)_{2}\right], 24.92\left[\mathrm{~s}, \mathrm{C}-8^{\prime} \mathrm{a} 2(\mathrm{~A}), \mathrm{CH}\left(\mathrm{CH}_{3}\right)_{2}\right], 25.32\left[\mathrm{~s}, \mathrm{C}-8^{\prime} \mathrm{b} 2(\mathrm{~A})\right.$, $\left.\mathrm{CH}\left(\mathrm{CH}_{3}\right)_{2}\right], 28.14$ [s, br, C-7'a (A) + C-7' $\left.(\mathrm{B}), \mathrm{CH}\left(\mathrm{CH}_{3}\right)_{2}\right], 28.31[\mathrm{~s}$, $\left.\mathrm{C}-7^{\prime} \mathrm{b}(\mathrm{A}), \mathrm{CH}\left(\mathrm{CH}_{3}\right)_{2}\right], 122.99$ [s, C-3'a (A) + C-4 $4^{\prime}(\mathrm{A})$ or $\left.\mathrm{C}-4^{\prime}(\mathrm{B})\right]$, $123.97\left[\mathrm{~s}, \mathrm{C}-3^{\prime} \mathrm{b}(\mathrm{A})\right], 124.42\left[\mathrm{~s}, \mathrm{C}-4^{\prime}(\mathrm{B})\right.$ or C-4' $\left.(\mathrm{A})\right], 126.32\left[\mathrm{~s}, \mathrm{C}-3^{\prime}\right.$ (B)], 128.95 [s, C-4 (A)], 129.69 [s, C-4 (B)], 131.96 [s, C-5 (B)], 132.47 [s, C-3 (A)], 132.94 [s, C-5 (A) and C-3 (B)], 135.53 [s, C-6 (A)], 136.06 [s, C-6 (B)], 138.57 [s, C-2' (B)], 139.00 [s, C-2 (B)], $139.47\left[\mathrm{~s}, \mathrm{C}-2^{\prime} \mathrm{b}(\mathrm{A})\right], 140.64\left[\mathrm{~s}, \mathrm{C}-2\right.$ (A) + C-2'a (A)], $144.69\left[\mathrm{~s}, \mathrm{C}-1^{\prime}\right.$ (A)], 148.15 [s, C-1' (B)], 148.53 [s, C-1 (B)], 160.00 [s, C-1 (A)], $164.74[\mathrm{~s}, \mathrm{C}-7$ (B), $\mathrm{CH}=\mathrm{N}], 168.76[\mathrm{~s}, \mathrm{C}-7(\mathrm{~A}), \mathrm{CH}=\mathrm{N}] .{ }^{19} \mathrm{~F}\left\{{ }^{1} \mathrm{H}\right\}$ $\mathrm{NMR}\left(282.4 \mathrm{MHz}, \mathrm{CDCl}_{3}\right): \delta-181.3$ (s). $\mathrm{MS}\left(\mathrm{ESI}+, \mathrm{CH}_{3} \mathrm{CN}\right): \mathrm{m} / z$ (\%) 649 (100) $\left[\mathrm{R}_{2} \mathrm{Sb}^{+}\right]\left[\mathrm{R}=2-\left(2^{\prime}, 6^{\prime}-{ }^{\mathrm{i}} \mathrm{Pr}_{2} \mathrm{C}_{6} \mathrm{H}_{3} \mathrm{~N}=\mathrm{CH}\right) \mathrm{C}_{6} \mathrm{H}_{4}\right]$.

Synthesis of $\left[2-\left(2^{\prime}, 6^{\prime}-{ }^{\mathrm{i}} \mathrm{Pr}_{2} \mathrm{C}_{6} \mathrm{H}_{3} \mathrm{~N}=\mathrm{CH}\right) \mathrm{C}_{6} \mathrm{H}_{4}\right] \mathrm{PhSbF}$ (6). A solution of $\left[\mathrm{Bu}_{4} \mathrm{~N}\right] \mathrm{F} \cdot 3 \mathrm{H}_{2} \mathrm{O}(0.262 \mathrm{~g}, 0.83 \mathrm{mmol})$ in acetonitrile $(10 \mathrm{~mL})$ was added to a solution of $2(0.505 \mathrm{~g}, 0.83 \mathrm{mmol})$ in acetonitrile $(20 \mathrm{~mL})$. The reaction mixture was stirred for $16 \mathrm{~h}$, while the color changed from colorless to yellow. The solvent was then removed in vacuum to obtain a yellow solid, which was extracted with $n$-hexane. Slow evaporation of the clear $n$-hexane solution gave yellow crystals of 6 (0.326 g, 82\%), m.p. 222-224 ${ }^{\circ} \mathrm{C}$. Anal. calc. for $\mathrm{C}_{25} \mathrm{H}_{27} \mathrm{FNSb}$ (482.25): C, 62.26; H, 5.64; N, 2.90. Found: C, 61.64; H, 5.93; N, 3.01\%. IR (ATR, $\left.\mathrm{cm}^{-1}\right): 1622(\mathrm{~s})$ $[\nu(\mathrm{CH}=\mathrm{N})] .{ }^{1} \mathrm{H} \mathrm{NMR}\left(400 \mathrm{MHz}, \mathrm{CDCl}_{3}\right): \delta 0.51\left[\mathrm{~d},{ }^{3} J_{\mathrm{H}, \mathrm{H}}=6.7 \mathrm{~Hz}\right.$, $\left.3 \mathrm{H}, \mathrm{H}-8^{\prime} \mathrm{a} 1, \mathrm{CH}\left(\mathrm{CH}_{3}\right)_{2}\right], 0.86\left[\mathrm{~d},{ }^{3} J_{\mathrm{H}, \mathrm{H}}=6.8 \mathrm{~Hz}, 3 \mathrm{H}, \mathrm{H}-8^{\prime} \mathrm{a} 2\right.$, $\left.\mathrm{CH}\left(\mathrm{CH}_{3}\right)_{2}\right], 1.12\left[\mathrm{~d},{ }^{3} J_{\mathrm{H}, \mathrm{H}}=6.8 \mathrm{~Hz}, 3 \mathrm{H}, \mathrm{H}-8^{\prime} \mathrm{b} 1, \mathrm{CH}\left(\mathrm{CH}_{3}\right)_{2}\right], 1.33$ $\left[\mathrm{d},{ }^{3} J_{\mathrm{H}, \mathrm{H}}=6.8 \mathrm{~Hz}, 3 \mathrm{H}, \mathrm{H}-8^{\prime} \mathrm{b} 2, \mathrm{CH}\left(\mathrm{CH}_{3}\right)_{2}\right], 1.82\left[\mathrm{sept},{ }^{3} J_{\mathrm{H}, \mathrm{H}}=6.8\right.$ $\mathrm{Hz}, 1 \mathrm{H}, \mathrm{H}-7^{\prime} \mathrm{a}, \mathrm{CH}\left(\mathrm{CH}_{3}\right)_{2}$ ], $3.05\left[\mathrm{sept},{ }^{3} J_{\mathrm{H}, \mathrm{H}}=6.8 \mathrm{~Hz}, 1 \mathrm{H}, \mathrm{H}-7^{\prime} \mathrm{b}\right.$, $\left.\mathrm{CH}\left(\mathrm{CH}_{3}\right)_{2}\right], 7.06\left(\mathrm{~m}, 1 \mathrm{H}, \mathrm{H}-3^{\prime} \mathrm{a}, \mathrm{C}_{6} H_{3}\right), 7.23\left(\mathrm{~m}, 5 \mathrm{H}, \mathrm{H}-3^{\prime} \mathrm{b}, \mathrm{H}-4^{\prime}\right.$, $\mathrm{C}_{6} \mathrm{H}_{3}+\mathrm{H}$-meta,para, $\left.\mathrm{C}_{6} \mathrm{H}_{5}\right), 7.42\left(\mathrm{~m}, 2 \mathrm{H}, \mathrm{H}\right.$-ortho, $\left.\mathrm{C}_{6} \mathrm{H}_{5}\right), 7.64$ $\left(\mathrm{dd},{ }^{3} J_{\mathrm{H}, \mathrm{H}}=7.4 \mathrm{~Hz}, 1 \mathrm{H}, \mathrm{H}-4, \mathrm{C}_{6} H_{4}\right), 7.81\left(\mathrm{~m}, 2 \mathrm{H}, \mathrm{H}-3, \mathrm{H}-5, \mathrm{C}_{6} H_{4}\right)$, $8.44\left(\mathrm{~m}, 2 \mathrm{H}, \mathrm{H}-6, \mathrm{C}_{6} \mathrm{H}_{4}+\mathrm{H}-7, \mathrm{CH}=\mathrm{N}\right) .{ }^{13} \mathrm{C}\left\{{ }^{1} \mathrm{H}\right\} \mathrm{NMR}(100.6 \mathrm{MHz}$, $\left.\mathrm{CDCl}_{3}\right): \delta 22.64 \quad\left[\mathrm{~s}, \mathrm{C}-8^{\prime} \mathrm{a} 1, \mathrm{CH}\left(\mathrm{CH}_{3}\right)_{2}\right], 24.25 \quad\left[\mathrm{~s}, \mathrm{C}-8^{\prime} \mathrm{b} 2\right.$, $\left.\mathrm{CH}\left(\mathrm{CH}_{3}\right)_{2}\right], 24.98\left[\mathrm{~s}, \mathrm{C}-8^{\prime} \mathrm{b} 1, \mathrm{CH}\left(\mathrm{CH}_{3}\right)_{2}\right], 26.21$ [s, C-8'a2, $\left.\mathrm{CH}\left(\mathrm{CH}_{3}\right)_{2}\right], 27.93 \quad\left[\mathrm{~s}, \mathrm{C}-7^{\prime} \mathrm{a}, \mathrm{CH}\left(\mathrm{CH}_{3}\right)_{2}\right], 28.81 \quad\left[\mathrm{~s}, \mathrm{C}-7^{\prime} \mathrm{b}\right.$, $\left.\mathrm{CH}\left(\mathrm{CH}_{3}\right)_{2}\right], 123.71$ (s, C-3'b), 123.93 (s, C-3'a), 126.67 (s, C-4'), 129.02 (s, C-meta), 129.35 (s, C-4), 129.46 (s, C-para), 132.49 (s, C3), 133.33 (s, C-5), 134.25 (d, ${ }^{3} J_{\mathrm{C}, \mathrm{F}}=1.0 \mathrm{~Hz}, \mathrm{C}-$ ortho), 134.92 (d, $\left.{ }^{3} J_{\mathrm{C}, \mathrm{F}}=9.9 \mathrm{~Hz}, \mathrm{C}-6\right), 139.45$ (s, C-2), 140.17 (s, C-2'b), 140.37 (s, C2'a), $143.27\left(\mathrm{~s}, \mathrm{C}-1^{\prime}\right), 147.72\left(\mathrm{~d},{ }^{2} J_{\mathrm{C}, \mathrm{F}}=9.2 \mathrm{~Hz}, \mathrm{C}-i p s o\right), 153.75$ (d, $\left.{ }^{2} J_{\mathrm{C}, \mathrm{F}}=6.3 \mathrm{~Hz}, \mathrm{C}-1\right), 168.43(\mathrm{~s}, \mathrm{C}-7, \mathrm{CH}=\mathrm{N}) .{ }^{19} \mathrm{~F}\left\{{ }^{1} \mathrm{H}\right\} \mathrm{NMR}(376.5$ $\mathrm{MHz}, \mathrm{CDCl}_{3}$ ): $\delta-174.7$ (s, br). $\mathrm{MS}\left(\mathrm{APCI}+, \mathrm{CH}_{3} \mathrm{CN}\right): \mathrm{m} / z(\%) 945$ (30) $\left[(\mathrm{RPhSb})_{2} \mathrm{~F}^{+}\right], 462(100)\left[\mathrm{RPhSb}^{+}\right]\left[\mathrm{R}=2-\left(2^{\prime}, 6^{\prime}-{ }^{\mathrm{i}} \mathrm{Pr}_{2} \mathrm{C}_{6} \mathrm{H}_{3} \mathrm{~N}=\right.\right.$ $\left.\mathrm{CH}) \mathrm{C}_{6} \mathrm{H}_{4}\right]$. 
Synthesis of $\left[2-\left(\mathrm{Me}_{2} \mathrm{NCH}_{2}\right) \mathrm{C}_{6} \mathrm{H}_{4}\right]_{2} \mathrm{SbF}$ (7). A solution of $\left[\mathrm{Bu}_{4} \mathrm{~N}\right] \mathrm{F} \cdot 3 \mathrm{H}_{2} \mathrm{O}(0.131 \mathrm{~g}, 0.42 \mathrm{mmol})$ in acetonitrile $(15 \mathrm{~mL})$ was added to a solution of $\left[\left\{2-\left(\mathrm{Me}_{2} \mathrm{NCH}_{2}\right) \mathrm{C}_{6} \mathrm{H}_{4}\right\}_{2} \mathrm{Sb}\right]^{+}\left[\mathrm{SbF}_{6}\right]^{-}$(4) $(0.260 \mathrm{~g}, 0.42 \mathrm{mmol})$ in acetonitrile $(15 \mathrm{~mL})$. The reaction mixture was stirred for $16 \mathrm{~h}$, then the solvent was removed in vacuum to yield a white solid, which was extracted with $n$ hexane. Slow evaporation of the clear $n$-hexane solution gave white crystals of $7(0.105 \mathrm{~g}, 62 \%)$, m.p. $64-66{ }^{\circ} \mathrm{C}$. Anal. calc. for $\mathrm{C}_{18} \mathrm{H}_{24} \mathrm{FN}_{2} \mathrm{Sb}$ (409.15): C, 52.84; H, 5.91; N, 6.85. Found: C, 52.56; H, 5.94; N, 6.99\%. ${ }^{1} \mathrm{H}$ NMR (300 MHz, $\mathrm{CDCl}_{3}$ ): $\delta 2.21$ (s, $\left.12 \mathrm{H}, \mathrm{H}-8, \mathrm{CH}_{3}\right), \mathrm{AB}$ spin system with $\mathrm{A}$ at 3.50 and $\mathrm{B}$ at $3.70 \mathrm{ppm}$ $\left({ }^{2} J_{\mathrm{H}, \mathrm{H}}=13.5 \mathrm{~Hz}, 4 \mathrm{H}, \mathrm{H}-7, \mathrm{CH}_{2}-\mathrm{N}\right), 7.26\left(\mathrm{~m}, 6 \mathrm{H}, \mathrm{H}-3,4,5, \mathrm{C}_{6} H_{4}\right)$, $7.68\left(\mathrm{~d},{ }^{3} \mathrm{~J}_{\mathrm{H}, \mathrm{H}}=5.5 \mathrm{~Hz}, 2 \mathrm{H}, \mathrm{H}-6, \mathrm{C}_{6} H_{4}\right) \cdot{ }^{13} \mathrm{C}\left\{{ }^{1} \mathrm{H}\right\} \operatorname{NMR}(75.5 \mathrm{MHz}$, $\mathrm{CDCl}_{3}$ ): $\delta 45.10$ (s, C-8), 65.78 (s, C-7), 127.67, 128.14, 128.77 (s, $\mathrm{C}-3, \mathrm{C}-4, \mathrm{C}-5), 135.21$ (d, $\left.{ }^{3} \mathrm{C}_{\mathrm{C}, \mathrm{F}}=4.0 \mathrm{~Hz}, \mathrm{C}-6\right), 143.72(\mathrm{~s}, \mathrm{C}-2)$, 150.15 (s, br, C-1). ${ }^{19} \mathrm{~F}\left\{{ }^{1} \mathrm{H}\right\}$ NMR $\left(282.4 \mathrm{MHz}, \mathrm{CDCl}_{3}\right): \delta-176.9$ (s, br). MS (ESI+, $\left.\mathrm{CH}_{3} \mathrm{CN}\right): m / z(\%) 409(3)\left[\mathrm{M}^{+}+\mathrm{H}\right], 389(100)$ $\left[\mathrm{R}_{2}^{\prime \prime} \mathrm{Sb}^{+}\right]\left[\mathrm{R}^{\prime \prime}=2-\left(\mathrm{Me}_{2} \mathrm{NCH}_{2}\right) \mathrm{C}_{6} \mathrm{H}_{4}\right]$.

Synthesis of [2-( $\left.\left.\mathrm{Me}_{2} \mathrm{NCH}_{2}\right) \mathrm{C}_{6} \mathrm{H}_{4}\right] \mathbf{P h S b F}$ (8). To a solution of $\left[2-\left(\mathrm{Me}_{2} \mathrm{NCH}_{2}\right) \mathrm{C}_{6} \mathrm{H}_{4}\right] \mathrm{PhSbCl}^{34}(0.500 \mathrm{~g}, 1.36 \mathrm{mmol})$ in THF $(20 \mathrm{~mL})$ was added $\mathrm{Ag}\left[\mathrm{SbF}_{6}\right](0.470 \mathrm{~g}, 1.36 \mathrm{mmol})$, resulting in the immediate formation of a white precipitate. The flask was covered with aluminum foil against light and the reaction mixture was stirred $3 \mathrm{~h}$, then filtered off through Celite, resulting in a colorless solution. Evaporation of the solvent in vacuum gave $0.70 \mathrm{~g}(87 \%)$ of crude $\left[\left\{2-\left(\mathrm{Me}_{2} \mathrm{NCH}_{2}\right) \mathrm{C}_{6} \mathrm{H}_{4}\right\}\right.$ $\mathrm{PhSb}]^{+}\left[\mathrm{SbF}_{6}\right]^{-}$as a white solid (m.p. $105-107{ }^{\circ} \mathrm{C}$ ) which was used without further purification. To a solution of this ionic species $(0.200 \mathrm{~g}, 0.34 \mathrm{mmol})$ in acetonitrile $(15 \mathrm{~mL})$ was added a solution of $\left[\mathrm{Bu}_{4} \mathrm{~N}\right] \mathrm{F} \cdot 3 \mathrm{H}_{2} \mathrm{O}(0.110 \mathrm{~g}, 0.35 \mathrm{mmol})$ in acetonitrile $(10 \mathrm{~mL})$. The reaction mixture was stirred for $16 \mathrm{~h}$, then the solvent was removed in vacuum to yield a white solid, which was extracted with $n$-hexane. Slow evaporation of the clear $n$-hexane solution gave white crystals of $8(0.051 \mathrm{~g}, 43 \%)$, m.p. $164-166^{\circ} \mathrm{C}$. Anal. calc. for $\mathrm{C}_{15} \mathrm{H}_{17} \mathrm{FNSb}$ (352.06): C, 51.17; $\mathrm{H}, 4.87 ; \mathrm{N}, 3.98$. Found: C, 50.76; $\mathrm{H}, 5.10 ; \mathrm{N}, 3.81 \% .{ }^{1} \mathrm{H}$ NMR $\left(300 \mathrm{MHz}, \mathrm{CDCl}_{3}\right)$ : $\delta 2.01$ (s, 3H, H-8a, $\left.\mathrm{CH}_{3}\right), 2.39$ (s, 3H, H-8b, $\left.\mathrm{CH}_{3}\right), 3.51(\mathrm{~s}, 2 \mathrm{H}, \mathrm{H}-$ 7, $\left.\mathrm{CH}_{2}-\mathrm{N}\right), 7.21\left(\mathrm{~d},{ }^{3} J_{\mathrm{H}, \mathrm{H}}=7.4 \mathrm{~Hz}, 1 \mathrm{H}, \mathrm{H}-3, \mathrm{C}_{6} H_{4}\right), 7.32(\mathrm{~m}, 3 \mathrm{H}$, H-meta,para, $\left.\mathrm{C}_{6} H_{5}\right), 7.37$ (dd, ${ }^{3} J_{\mathrm{H}, \mathrm{H}}=7.4 \mathrm{~Hz}, 1 \mathrm{H}, \mathrm{H}-4, \mathrm{C}_{6} H_{4}$ ), $7.47\left(\mathrm{dd},{ }^{3} J_{\mathrm{H}, \mathrm{H}}=7.3 \mathrm{~Hz}, 1 \mathrm{H}, \mathrm{H}-5, \mathrm{C}_{6} H_{4}\right), 7.52(\mathrm{~m}, 2 \mathrm{H}, \mathrm{H}-$ ortho, $\left.\mathrm{C}_{6} H_{5}\right), 8.16\left(\mathrm{~d},{ }^{3} J_{\mathrm{H}, \mathrm{H}}=7.3 \mathrm{~Hz}, 1 \mathrm{H}, \mathrm{H}-6, \mathrm{C}_{6} H_{4}\right) .{ }^{13} \mathrm{C}\left\{{ }^{1} \mathrm{H}\right\} \operatorname{NMR}(75.5$ $\mathrm{MHz}, \mathrm{CDCl}_{3}$ ): $\delta 45.48,45.50$ (s, C-8a, C-8b), 65.45 (s, C-7), 126.51 (s, C-3), 128.32 (s, C-5), 128.90 (s, C-meta), 129.18 (s, C-4), 129.46 (s, C-para), 134.67 (d, ${ }^{3} \mathrm{~J}_{\mathrm{C}, \mathrm{F}}=1.1 \mathrm{~Hz}, \mathrm{C}-$ ortho, $\left.C_{6} \mathrm{H}_{5}\right), 135.22(\mathrm{~d}$, $\left.{ }^{3} J_{\mathrm{C}, \mathrm{F}}=6.9 \mathrm{~Hz}, \mathrm{C}-6\right), 143.22(\mathrm{~s}, \mathrm{C}-2), 144.07\left(\mathrm{~d},{ }^{2} J_{\mathrm{C}, \mathrm{F}}=10.1 \mathrm{~Hz}, \mathrm{C}-\right.$ ipso), 148.27 (d, $\left.{ }^{3} J_{\mathrm{C}, \mathrm{F}}=7.7 \mathrm{~Hz}, \mathrm{C}-1\right) .{ }^{19} \mathrm{~F}\left\{{ }^{1} \mathrm{H}\right\} \mathrm{NMR}(282.4 \mathrm{MHz}$, $\left.\mathrm{CDCl}_{3}\right): \delta-169.2$ (s, br). MS (ESI+, $\mathrm{CH}_{3} \mathrm{CN}$ ): $m / z(\%) 332$ (100) $\left[\mathrm{R}^{\prime \prime} \mathrm{PhSb}^{+}\right]\left[\mathrm{R}^{\prime \prime}=2-\left(\mathrm{Me}_{2} \mathrm{NCH}_{2}\right) \mathrm{C}_{6} \mathrm{H}_{4}\right]$.

\section{Conclusions}

The present work reports on a new general method for the synthesis of hypervalent diorganoantimony(III) fluorides containing either one or two organic ligands with a pendant arm, e.g. $\left[2-\left(2^{\prime}, 6^{\prime}-{ }^{\mathrm{i}} \mathrm{Pr}_{2} \mathrm{C}_{6} \mathrm{H}_{3} \mathrm{~N}=\mathrm{CH}\right) \mathrm{C}_{6} \mathrm{H}_{4}\right]_{2} \mathrm{SbF}(5), \quad\left[2-\left(2^{\prime}, 6^{\prime}-{ }^{\mathrm{i}} \mathrm{Pr}_{2} \mathrm{C}_{6} \mathrm{H}_{3}-\right.\right.$ $\left.\mathrm{N}=\mathrm{CH}) \mathrm{C}_{6} \mathrm{H}_{4}\right] \mathrm{PhSbF}$ (6) (Scheme 1), $\left[2-\left(\mathrm{Me}_{2} \mathrm{NCH}_{2}\right) \mathrm{C}_{6} \mathrm{H}_{4}\right]_{2} \mathrm{SbF}$ (7) and $\left[2-\left(\mathrm{Me}_{2} \mathrm{NCH}_{2}\right) \mathrm{C}_{6} \mathrm{H}_{4}\right] \mathrm{PhSbF}$ (8), using as starting materials diorganoantimony(III) cations stabilized by intramolecular $\mathrm{N} \rightarrow \mathrm{Sb}$ interactions. It is worthwhile to mention that the diorganoantimony(III) fluorides could be obtained just by $\left[\mathrm{Bu}_{4} \mathrm{~N}\right] \mathrm{F} \cdot 3 \mathrm{H}_{2} \mathrm{O}$ addition to in situ prepared cationic species. The ionic species $\left[\left\{2-\left(2^{\prime}, 6^{\prime}-{ }^{\mathrm{i}} \mathrm{Pr}_{2} \mathrm{C}_{6} \mathrm{H}_{3} \mathrm{~N}=\mathrm{CH}\right) \mathrm{C}_{6} \mathrm{H}_{4}\right\}_{2} \mathrm{Sb}\right]^{+}\left[\mathrm{PF}_{6}\right]^{-}$ (1) and $\left[\left\{2-\left(2^{\prime}, 4^{\prime}, 6^{\prime}-\mathrm{Me}_{3} \mathrm{C}_{6} \mathrm{H}_{2} \mathrm{~N}=\mathrm{CH}\right) \mathrm{C}_{6} \mathrm{H}_{4}\right\}_{2} \mathrm{Sb}^{+}\left[\mathrm{PF}_{6}\right]\right.$ exhibit helical chirality and crystallize as $1: 1$ mixture of $\left(\Delta_{\mathrm{Sb}}\right)$ and $\left(\Lambda_{\mathrm{Sb}}\right)$-cations. In contrast to $\mathrm{Ph}_{2} \mathrm{SbF}$, which exhibits a chain polymeric structure based on almost symmetric $\mathrm{Sb}-\mathrm{F} \cdots \mathrm{Sb}$ bridges, the crystals of the novel fluorides 5-8 contain discrete molecules as result of intramolecular $\mathrm{N} \rightarrow \mathrm{Sb}$ interactions.

\section{Acknowledgements}

Financial support from National Research Council of Romania (CNCS, Research Project No. PN-II-ID-PCE-2011-3-0933) is greatly appreciated. A. M. P. thanks the European Social Fund for a Scholarship (Education and Training Program 2008-2013, POSDRU/6/1.5/S/3). We also thank DAAD (program "Ostpartnerschaften") for financial support and Technische Universität Chemnitz for providing research facilities during research stays of A. M. P. The support provided by the NATIONAL CENTER FOR X-RAY DIFFRACTION (Babeş-Bolyai University, ClujNapoca, Romania) for the solid state structure determinations is highly acknowledged.

\section{References}

1 M. Jean, Anal. Chim. Acta, 1971, 57, 438-439.

2 C. R. Wade and F. P. Gabbaï, Organometallics, 2011, 30, 44794481.

3 C. R. Wade, I.-S. Ke and F. P. Gabbaï, Angew. Chem., Int. Ed., 2012, 51, 478-481, and references cited therein.

4 I.-S. Ke, M. Myahkostupov, F. N. Castellano and F. P. Gabbaï, J. Am. Chem. Soc., 2012, 134, 15309-15311.

5 I.-S. Ke, J. S. Jones and F. P. Gabbaï, Angew. Chem., Int. Ed., 2014, 53, 2633-2637.

6 J. S. Jones, C. R. Wade and F. P. Gabbaï, Organometallics, 2015, 34, 2647-2654.

7 R. Müller and C. Dathe, Chem. Ber., 1966, 99, 1609-1613.

8 S. P. Bone and D. B. Sowerby, J. Chem. Soc., Dalton Trans., 1979, 1430-1433.

9 K. Ohkata, S. Takemoto, M. Ohnishi and K.-Y. Akiba, Tetrahedron Lett., 1989, 30, 4841-4844.

10 L. Baiget, M. Bouslikhane, J. Escudié, G. Cretiu Nemes, I. Silaghi-Dumitrescu and L. Silaghi-Dumitrescu, Phosphorus, Sulfur Silicon Relat. Elem., 2003, 178, 1949-1961. 11 L. Baiget, H. Ranaivonjatovo, J. Escudié, G. Cretiu Nemes, I. Silaghi-Dumitrescu and L. Silaghi-Dumitrescu, J. Organomet. Chem., 2005, 690, 307-312.

12 L. Baiget, R. El Ayoubi, H. Ranaivonjatovo, J. Escudié and H. Gornitzka, J. Organomet. Chem., 2008, 693, 2293-2298.

13 L. Dostál, R. Jambor, A. Růžička, R. Jirásko, I. Císařová and J. Holeček, J. Fluorine Chem., 2008, 129, 167-172.

14 A. Fridrichová, T. Svoboda, R. Jambor, Z. Padělková, A. Rưžička, M. Erben, R. Jirásko and L. Dostál, Organometallics, 2009, 28, 5522-5528. 
15 M. Nunn, D. B. Sowerby and D. Wesolek, J. Organomet. Chem., 1983, 251, C45-C46.

16 G. Becker, O. Mundt, M. Sachs, H. J. Breunig, E. Lork, J. Probst and A. Silvestru, Z. Anorg. Allg. Chem., 2001, 627, 699-714.

17 L. M. Opriş, A. Silvestru, C. Silvestru, H. J. Breunig and E. Lork, Dalton Trans., 2003, 4367-4374.

18 A. M. Preda, C. I. Raţ, C. Silvestru, H. J. Breunig, H. Lang, T. Rüffer and M. Mehring, Dalton Trans., 2013, 42, 11441158.

19 C. J. Carmalt, D. Walsh, A. H. Cowley and N. C. Norman, Organometallics, 1997, 16, 3597-3600.

20 H. Althaus, H. J. Breunig and E. Lork, Chem. Commun., 1999, 1971-1972.

21 C. Hering, M. Lehmann, A. Schulz and A. Villinger, Inorg. Chem., 2012, 51, 8212-8224.

22 J. W. Wielandt, N. L. Kilah, A. C. Willis and S. B. Wild, Chem. Commun., 2006, 3679-3680.

23 N. L. Kilah, S. Petrie, R. Stranger, J. W. Wielandt, A. C. Willis and S. B. Wild, Organometallics, 2007, 26, 6106-6113.

24 S. S. Chitnis, N. Burford, R. McDonald and M. J. Ferguson, Inorg. Chem., 2014, 53, 5359-5372.

25 L. Dostál, R. Jambor, I. Císařová, L. Beneš, A. Růžička, R. Jirásko and J. Holeček, J. Organomet. Chem., 2007, 692, 2350-2353.

26 K. Nakamoto, Infrared and Raman Spectra of Inorganic and Coordination Compounds, Part A: Theory and Applications in Inorganic Chemistry, John Wiley \& Sons, Hoboken, New Jersey, 6th edn, 2009.

27 J. Emsley, Die Elemente, Walter de Gruyter, Berlin, 1994.

28 Nomenclature of Inorganic Chemistry - IUPAC Recommendations, ed. N. G. Connelly, T. Damhus, R. M. Hartshorn and A. T. Hutton, RSC Publishing, Cambridge, 2005.

29 M. Nishio, Phys. Chem. Chem. Phys., 2011, 13, 13873-13900.
30 L. Dostál, R. Jambor, A. Růžička and P. Šimon, Eur. J. Inorg. Chem., 2011, 2380-2386.

31 C. J. Carmalt, A. H. Cowley, R. D. Culp, R. A. Jones, S. Kamepalli and N. C. Norman, Inorg. Chem., 1997, 36, 2770-2776.

32 I. Urbanová, R. Jambor, A. Růžička, R. Jirásko and L. Dostál, Dalton Trans., 2014, 43, 505-512.

33 D. Copolovici, F. Isaia, H. J. Breunig, C. I. Raţ and C. Silvestru, RSC Adv., 2014, 4, 26569-26576.

34 D. Copolovici, V. R. Bojan, C. I. Raţ, A. Silvestru, H. J. Breunig and C. Silvestru, Dalton Trans., 2010, 39, 6410-6418.

35 Chemistry of Hypervalent Compounds, ed. K.-Y. Akiba, WileyVCH, New York, 1999.

36 The $N-X-L$ nomenclature system has been described previously: $N$ valence shell electrons about a central atom $\mathrm{X}$ with $L$ ligands; C. W. Perkins, J. C. Martin, A. J. Arduengo III, W. Lau, A. Alegria and K. Kochi, J. Am. Chem. Soc., 1980, 102, 7753-7759.

37 C. I. Raţ, C. Silvestru and H. J. Breunig, Coord. Chem. Rev., 2013, 257, 818-879.

38 Nomenclature of Organic Chemistry, Sections A, B, C, D, E, F and $H$, ed. J. Rigaudy and S. P. Klesney, Pergamon Press, Oxford, 1979.

39 A. Silvestru and C. Silvestru, Stud. Univ. Babes-Bolyai, Chem., 1998, 43, 273-280.

40 G. R. Fulmer, A. J. M. Miller, N. H. Sherden, H. E. Gottlieb, A. Nudelman, B. M. Stoltz, J. E. Bercaw and K. I. Goldberg, Organometallics, 2010, 29, 2176-2179.

41 MestReNova, Mestrelab Research S. L., A Coruña 15706, Santiago de Compostela.

42 G. M. Sheldrick, SHELXL-97, Program for the Solution of Crystal Structures, University of Göttingen, Göttingen, Germany, 1997.

43 DIAMOND-Visual Crystal Structure Information System, Crystal Impact: Postfach 1251, D-53002 Bonn, Germany, 2001. 